\title{
Bilim İnsanlarının Finansal Okuryazarlık Tutum ve Davranışları Üzerine Bir Araştırma: Niğde Ömer Halisdemir Üniversitesi Örneği ${ }^{12}$
}

\author{
Fevzi Serkan ÖZDEMIR ${ }^{3}$ - Haluk BENGÜ ${ }^{4}$ - Elif BULUT ${ }^{5}$ Serpil ÇELIK ${ }^{6}$
}

Başvuru Tarihi: 20.11.2020

Kabul Tarihi: 03.06 .2021

Makale Türü: Araştırma Makalesi

\section{Öz}

Okuryazarlık kavramına dair ilk tanımlamalara bakıldiğında; bireyin "okuma" ve "yazma yetisi"ne yapılan vurgu göze çarpmaktadır. Ancak okuryazarlık kavramının bu iki yeti ile sınırlanamayacağının anlaşılması ile kavram "okuduğunu anlama" ve "kendini yazılı olarak da ifade edebilme" yetilerini de içine alacak biçimde genişlemiştir. Özellikle teknolojik ilerlemenin ve kitle iletişim araçlarının yaygınlaşması ile okuryazarlık kavramının tanımsal gelişimi devam etmiş, bileşenleri ile çeşitlenen özelleşmiş okuryazarlık tanımları da literatüre geçmiştir. Öyle ki okuryazarlık kavramı, belirli özel veya teknik bir alanda okuryazarlığı ifade edecek biçimde kullanılmaya başlamıştır. Örneğin finans, ekonomi, medya vb. gibi birçok alanda okuryazarliktan söz edilmeye başlanmıştır. Finans alanında okuryazarlık da son yılların popüler kavramlarından biri haline gelmiştir. Finansal okuryazarlık hakkında çok sayıda araştırma literatürdeki yerini almıştır. Bu çalışmanın amacı da bilim insanları arasında finansal okuryazarlık tutum ve davranış ölçeğinin harcama, algı, ilgi ve tutum şeklindeki bileşenleri açısından farklılık olup olmadığını ve bilim insanlarının finansal kavramlara dair bilgi düzeyleri ile tutum ve davranış ölçeğinin bileşenleri arasında ilişki olup olmadığını irdelemektir. Çalışmanın anakütlesini oluşturan Niğde Ömer Halisdemir Üniversitesi'nde görev yapan 951 akademik personele kolayda örnekleme yoluyla anket uygulanmıştır. Sağlanan geçerli gözlem sayısı ise 247 olmuştur. Bu sayı \%95 anlam düzeyinde, \%5,37 hata payına karşıllk gelmektedir. Çalışma sonucunda; demografik değişenlerden cinsiyet, unvan, ekonomik gelişmeleri takip etme, yaş ve finansal kavramlardan tasarruf, hisse senedi, yatırım fonu, katılım bankası, bireysel emeklilik, yatırım, enflasyon, çek ile finansal okuryazarlık tutum ve davranış bileşenleri arasında anlamli farklilıklar tespit edilmiştir.

Anahtar Kelimeler: Finansal Tutum, Finansal Davranış, Finansal Okuryazarlı

Atıf: Özdemir, F. S., Bengü, H., Bulut, E. ve Çelik, S. (2021). Bilim insanlarının finansal okuryazarlık tutum ve davranışları üzerine bir araştırma: Niğde Ömer Halisdemir Üniversitesi örneği. Anadolu Üniversitesi Sosyal Bilimler Dergisi, 21(2), 449-482.

\footnotetext{
1 Bu araştırma kapsamında, “Niğde Ömer Halis Demir Üniversitesi Etik Kurulu”na başvuru yapılmış olup, 29.05.2019 tarihinde 2019/05-04 sayılı kararı ile etik açıdan uygunluk belgesi alınmıştır.

2 Bu çalışma 6. Uluslararası Muhasebe ve Finans Araştırmaları Kongresi (ICARF'19)'inde (23-25 Ekim 2019, Niğde) sözlü bildiri olarak sunulmuştur.

3 Türkiye Büyük Millet Meclisi, fsozdemir@gmail.com, ORCID: 0000-0002-0641-6352

${ }^{4}$ Niğde Ömer Halisdemir Üniversitesi, İktisadi ve İdari Bilimler Fakültesi İşletme Bölümü, halukbengu@gmail.com, ORCID: 0000-0001-7751-0285

Ondokuz Mayıs Üniversitesi, İktisadi ve İdari Bilimler Fakültesi İşletme Bölümü, elif@omu.edu.tr, ORCID: 0000-0001-8278-1821

${ }^{6}$ Niğde Ömer Halisdemir Üniversitesi Niğde Sosyal Bilimler Meslek Yüksekokulu Muhasebe ve Vergi Bölümü, serpilcelik@ohu.edu.tr, ORCID: 00000002-2340-0010
} 


\title{
An Investigation of Scientists' Financial Literacy Attitudes and Behaviors: The Case of Niğde Ömer Halisdemir University
}

\author{
Fevzi Serkan ÖZDEMIR ${ }^{7}$ - Haluk BENGÜ ${ }^{8}$ - Elif BULUT ${ }^{9}$ - Serpil ÇELIK ${ }^{10}$
}

Submitted by: 20.11 .2020

Accepted by: 03.06.2021

Article Type: Research Article

\begin{abstract}
Considering the first definitions about the concept of literacy; emphasis is placed on the individual's ability to read and write. However, it has been understood that the concept of literacy cannot be limited by these two skills. The concept has expanded to include "reading comprehension" and "expressing yourself in writing". Especially, technological advances and the widespread use of mass media have also literally developed the concept of literacy. And the definitions of specialized literacy, which are diversified with their components, are also included in the literature. Thus, the concept of literacy has begun to be used to express literacy in a particular or specific technical field. For example, finance, economics, media, etc. literacy has started to be mentioned in many areas such as. Literacy in finance has also become one of the popular concepts of recent years. There are many studies on financial literacy in the literature. The aim of this study is to examine whether there is a difference between the scientists in terms of the components of financial attitude and behavior scale in terms of expenditure, perception, interest and attitude, and whether there is a relationship between academics' level of knowledge of financial concepts and the components of attitude and behavior scale. The study was conducted by 951 academic staff working at Niğde Ömer Halisdemir University. The number of valid observations provided was 247. This number corresponds to a 5.37\% margin of error at 95\% significance level. As a result of the study, there were significant differences between financial literacy attitude and behavior components and demographic variables (gender, title, age, following economic developments), and financial concepts (savings, stocks, mutual funds, Islamic banking, private pensions, investment, inflation, check).
\end{abstract}

Keywords: Financial Attitude, Financial Behavior, Financial Literacy

\footnotetext{
Grand National Assembly of Turkey, fsozdemir@gmail.com, ORCID: 0000-0002-0641-6352

8 Niğde Ömer Halisdemir University Faculty of Economics and Administrative Sciences Business Department, halukbengu@gmail.com, ORCID; 0000-0001-7751-0285

9 Ondokuz Mayıs University Faculty of Economics and Administrative Sciences Business Department, elif@omu.edu.tr, ORCID: 0000-0001-82781821

${ }^{10}$ Niğde Ömer Halisdemir University Niğde Vocational School of Social Sciences Accounting and Tax Department, serpilcelik@ohu.edu.tr, ORCID: 0000-0002-2340-0010
} 


\section{Giriş}

Türk Dil Kurumu Sözlügü̈nde “Okuryazarlık” kavramı, "Okuryazar olma hali”; “Okuryazar” ise, "Okuması yazması olan, öğrenim görmüş (kimse)” şeklinde tanımlanmaktadır. Bileşik kelime olan "okuryazarlık”, sözlükte de bu iki eylem ile tanımlanmaktadır. Kavramın ilk bakışta bir bireyin "okuma” ve "yazma" yetisine sahip olması halini çağrıştırmasının ana nedeni de budur.

Öte yandan okuryazarlık kavramının ilk defa tanımlandığı 1950'li yıllarda da tanımın bu iki beceri ile sınırlandırıldığı görülmüştür. Bu yılları izleyen dönemde okuryazarlığın, bireyin "okuma" ve "yazma" becerisi ile sınırlanamayacak kadar geniş bir anlam taşıdığının kabul görmeye başlaması, "okuduğunu anlama" ve "kendini yazılı olarak ifade etme" yetilerinin de bu kavramın içine girmesine sebep olmuştur (Güneş, 1997).

"Okumak" ve "yazmak" eylemleri ilk anlamları ile yazı sembollerini kullanmak ve yine aynı yazı sembolleriyle oluşturulan anlamı çözmektir. "Okuma" kelimesinin ilk anlamı dışında, mecazî anlamda (gözlerinden okumak) ve gerçek anlamda (grafik okumak) gibi yazıyı okuma eyleminden daha geniş bir anlamı da bulunmaktadır. Yazı sembollerinin yanında binlerce sembolik anlatım da söz konusu olduğundan bütün bu sembolleri anlamlandırmaya çalışmanın kendisi de bir tür okuma şekli olarak değerlendirilmektedir. Öyle ki, farkına vararak veya farkına varmadan da çevrenin, bireyin kendisinin, etrafta olup bitenlerin ve olayların okunduğu; bazen de yine semboller kullanılarak bireyin kendisini ifade etmek için yazılar yazması da yine okuryazarlık kavramı içinde değerlendirilmektedir (Altun, 2005; Aşıcı, 2009).

Geçmişte insanlık için önemli bir beceri olan okuryazarlık, günümüzde, bilhassa gelişmiş toplumlar için bilinç dışı yeterlik haline gelmiştir. Bu gelişme çeşitli nedenlere bağlanmaktadır. Bunlardan biri de teknolojideki hızlı değişim ve dönüşümdür. Öyle ki okuryazarlık kavramı, belirli özel veya teknik bir alanda okuryazarlı̆ğ ifade edecek biçimde kullanılmaya başlamıştır. Örneğin finans, ekonomi, teknoloji, internet, medya, görsel, eleştirel, bilgisayar vb. gibi birçok alanda okuryazarlıktan söz edilmeye başlanmıştır.

Birleşmiş Milletler tarafından 1990 yılının “uluslararası okuryazarlık yılı” olarak ilan edilmesi de okuryazarlık kavramının önemini pekiştirmiş ve literatürde okuryazarlığın yanı sıra okuryazarlık türlerine ilişkin çalışmalar da yerini almaya başlamıştır (Kurt vd., 2014).

Finans alanında okuryazarlık da son yılların popüler kavramlarından biri haline gelmiştir. Öyle ki, finansal okuryazarlık hakkında çok sayıda bilimsel araştırma, literatürdeki yerini almıştır. Bu çalışmanın amacı da bilim insanları arasında finansal okuryazarlı tutum ve davranış ölçeğinin harcama, algı, ilgi ve tutum şeklindeki bileşenleri açısından farklılık olup olmadığını ve bilim insanlarının finansal kavramlara dair bilgi düzeyleri ile tutum ve davranış ölçeğinin bileşenleri arasında ilişki olup olmadiğını irdelemektir.

\section{Literatür Taraması}

Finansal okuryazarlık, son yılların popüler çalışma konularından biri haline gelmiştir. Finansal okuryazarlığı konu edinen birçok çalışma Tablo 1'de kronolojik olarak sıralanmıştır. Yayının adı, yazar(lar)1, yayımlandığı yıl, yayımlandığı veya sunulduğu yer ile çalışmanın amacı ve edinilen bulgular toplulaştırılmıştır.

Literatürdeki çalışmalardan Lusardi vd. (2009), Cole vd. (2009), Lusardi vd. (2010), Klapper vd. (2012), Bayrakdaroğlu ve Şan (2014), Kaderli vd. (2016), Güler ve Tunahan (2017), Aksoylu vd. (2017), Güney ve Tanyıldızı (2018), Kıran ve Bozkurt (2019), Ünal vd. (2019) katılımcıların finansal okuryazarlık düzeylerini ele alırken; Öztürk ve Demir (2015), Ünal ve Düger (2015), Gutnu ve Cihangir (2015), Çelikkol vd. (2017), Durmuşkaya ve Kavas (2018) akademisyenlerin finansal okuryazarlık düzeylerine dair incelemede bulunmuştur.

Ayrıca literatürde çoğunlukla, katılımcıların finansal okuryazarlık düzeylerinin tespit edilmesinin amaçlandığı görülmüştür. Finansal okuryazarlık tutum ve davranışlarının incelenmesine yönelik çalışmaların ise 
çoğunlukla üniversite öğrencilerine yönelik olduğu gözlenmektedir. Buna karşın salt akademisyenlerin finansal okuryazarlık tutum ve davranışını ele alan bir çalışmaya rastlanılamamıştır. Bu husus, bilim insanlarının finansal okuryazarlık tutum ve davranış biçimlerinin araştırılmasının temel motivasyonunu oluşturmuştur.

Tablo 1

Finansal Okuryazarlığı Konu Alan Çalışmalar

\begin{tabular}{|c|c|c|c|c|c|}
\hline Yayının Adı & Yazar(lar)1 & Yil1 & $\begin{array}{l}\text { Yayımlandiğı } \\
\text { / Sunulduğu } \\
\text { Yer }\end{array}$ & $\begin{array}{c}\text { Çalışmanın } \\
\text { Amacı }\end{array}$ & Edinilen Bulgular \\
\hline $\begin{array}{l}\text { Financial } \\
\text { Literacy: An } \\
\text { Essential Tool } \\
\text { for Informed } \\
\text { Consumer } \\
\text { Choice? }\end{array}$ & $\begin{array}{l}\text { Annamaria } \\
\text { LUSARDI }\end{array}$ & 2008 & $\begin{array}{l}\text { Nber Working } \\
\text { Paper Series } \\
\text { National } \\
\text { Bureau of } \\
\text { Economic } \\
\text { Research }\end{array}$ & $\begin{array}{l}\text { Çalışmanın amacı } \\
\text { katılımcıların } \\
\text { finansal } \\
\text { okuryazarlık } \\
\text { düzeyini } \\
\text { belirlemektir. }\end{array}$ & $\begin{array}{l}\text { Çalışmaya } 812 \text { kişi katılmıştır. } \\
\text { Çalışmaya katılan bireylerin bileşik } \\
\text { faiz, nominal ve gerçek değerler } \\
\text { arasındaki fark ve risk } \\
\text { çeşitlendirmesinin esasları gibi temel } \\
\text { finansal kavramlar konusundaki } \\
\text { eksikliği ve temel ekonomik } \\
\text { hesaplamaları yapamadığı tespit } \\
\text { edilmiştir. }\end{array}$ \\
\hline $\begin{array}{l}\text { Financial } \\
\text { Literacy and } \\
\text { Financial } \\
\text { Sophistication } \\
\text { among Older } \\
\text { Americans }\end{array}$ & $\begin{array}{c}\text { Annamaria } \\
\text { LUSARDI, } \\
\text { Olivia S. } \\
\text { MITCHELL } \\
\text { Vilsa } \\
\text { CURTO }\end{array}$ & 2009 & $\begin{array}{l}\text { Nber Working } \\
\text { Paper Series } \\
\text { National } \\
\text { Bureau of } \\
\text { Economic } \\
\text { Research }\end{array}$ & $\begin{array}{l}\text { Çalışma } 55 \text { yaş } \\
\text { üstü } \\
\text { Amerikalıların } \\
\text { finansal } \\
\text { okuryazarlık ve } \\
\text { finansal } \\
\text { gelişmişlik } \\
\text { düzeylerini tespit } \\
\text { etmeyi } \\
\text { amaçlamaktadır. }\end{array}$ & $\begin{array}{llr}\text { Çalışmaya } & 1332 \text { kişi } & \text { katılmıştır. } \\
\text { Çalışma } & \text { sonucunda } & \text { finansal } \\
\text { okuryazarlığın yaşlı bireyler arasında } & \text { düşük olduğu tespit edilmiş̧tir. }\end{array}$ \\
\hline $\begin{array}{l}\text { Financial } \\
\text { Literacy, } \\
\text { Financial } \\
\text { Decisions, and } \\
\text { The Demand for } \\
\text { Financial } \\
\text { Services: } \\
\text { Evidence from } \\
\text { India and } \\
\text { Indonesia } \\
\end{array}$ & $\begin{array}{l}\text { Shawn } \\
\text { COLE, } \\
\text { Thomas } \\
\text { SAMPSON, } \\
\text { Bilal ZIA }\end{array}$ & 2009 & $\begin{array}{c}\text { Working } \\
\text { Paper }\end{array}$ & $\begin{array}{l}\text { Çalışma } \\
\text { Endonezya ve } \\
\text { Hindistan'da } \\
\text { yaşayan } \\
\text { katılımcıların } \\
\text { finansal } \\
\text { okuryazarlık } \\
\text { düzeyini tespit } \\
\text { etmeyi } \\
\text { amaçlamıştır. } \\
\end{array}$ & \begin{tabular}{|lccr} 
Çalışmaya & 4689 kişi & katılmıştır. \\
Çalışma & sonucunda & finansal \\
okuryazarlığın $\quad$ bireyler & arasında \\
düşük olduğunu görülmüştür.
\end{tabular} \\
\hline $\begin{array}{l}\text { Financial } \\
\text { Literacy among } \\
\text { The Young: } \\
\text { Evidence and } \\
\text { Implications for } \\
\text { Consumer } \\
\text { Policy }\end{array}$ & $\begin{array}{l}\text { Annamaria } \\
\text { LUSARDI, } \\
\text { Olivia S. } \\
\text { MITCHELL } \\
\text { Vilsa } \\
\text { CURTO }\end{array}$ & 2010 & $\begin{array}{l}\text { Nber Working } \\
\text { Paper Series } \\
\text { National } \\
\text { Bureau of } \\
\text { Economic } \\
\text { Research }\end{array}$ & $\begin{array}{l}\text { Çalışmanın amacı } \\
\text { ABD'deki } \\
\text { gençlerin finansal } \\
\text { okuryazarlık ve } \\
\text { finansal } \\
\text { gelişmişlik } \\
\text { düzeylerini tespit } \\
\text { etmektir. } \\
\end{array}$ & \begin{tabular}{|lrrr} 
Çalışmaya & 7138 & kişi & katılmıştır. \\
Çalışma & sonucunda & finansal \\
okuryazarlık & düzeyinin & gençler \\
arasinda & düşük & olduğu & tespit \\
edilmiştir. & & &
\end{tabular} \\
\hline $\begin{array}{l}\text { Financial } \\
\text { Literacy and } \\
\text { Retirement } \\
\text { Planning in The } \\
\text { Netherlands }\end{array}$ & $\begin{array}{l}\text { Maarten } \\
\text { VAN } \\
\text { ROOIJ, } \\
\text { Annamaria } \\
\text { LUSARDI, } \\
\text { Rob } \\
\text { ALESSIE }\end{array}$ & 2011 & $\begin{array}{l}\text { Journal of } \\
\text { Economic } \\
\text { Psychology }\end{array}$ & $\begin{array}{l}\text { Çalışmanın amacı } \\
\text { Hollanda'da } \\
\text { finansal } \\
\text { okuryazarlık ve } \\
\text { emeklilik } \\
\text { planlaması } \\
\text { ilişkisinin } \\
\text { incelenmesidir. } \\
\end{array}$ & $\begin{array}{l}\text { Çalışmaya } 1508 \text { kişi katılmıştır. } \\
\text { Çalışmada finansal bilgi ve emeklilik } \\
\text { planlaması arasında güçlü ve pozitif } \\
\text { bir ilişki olduğu tespit edilmiştir. }\end{array}$ \\
\hline $\begin{array}{l}\text { Financial } \\
\text { Literacy and The } \\
\text { Financial Crisis }\end{array}$ & $\begin{array}{l}\text { Leora } \\
\text { KLAPPER, } \\
\text { Annamaria } \\
\text { LUSARDI, } \\
\text { Georgios A. } \\
\text { PANOS }\end{array}$ & 2012 & $\begin{array}{l}\text { Policy } \\
\text { Research } \\
\text { Working } \\
\text { Paper }\end{array}$ & $\begin{array}{l}\text { Çalışma finansal } \\
\text { okuryazarlık } \\
\text { düzeyini tespit } \\
\text { etmek ve finansal } \\
\text { okuryazarlığın } \\
\text { davranış } \\
\text { üzerindeki } \\
\text { etkilerini } \\
\text { incelemeyi } \\
\text { amaçlamaktadır. } \\
\end{array}$ & \begin{tabular}{|lrr} 
Çalışmaya & 1600 kişi katılmıştır. \\
Çalışma & sonucunda & finansal \\
okuryazarlığın katılımcılar arasında \\
düşük olduğu, özellikle düşük gelirli \\
ve düşük eğitim seviyesine sahip \\
kırsal alanda yaşayan kadınlarda daha \\
da düşük seviyede olduğu tespit \\
edilmiştir.
\end{tabular} \\
\hline
\end{tabular}


Tablo 1 (Devamı)

Finansal Okuryazarlığı Konu Alan Çalışmalar

\begin{tabular}{|c|c|c|c|c|c|}
\hline Yayının Adı & Yazar(lar)1 & Y1l1 & $\begin{array}{l}\text { Yayınlandığı } \\
\text { / Sunulduğu } \\
\text { Yer }\end{array}$ & Çalışmanın Amacı & Edinilen Bulgular \\
\hline $\begin{array}{l}\text { The Effects of } \\
\text { Financial } \\
\text { Literacy on } \\
\text { The } \\
\text { Borrowing } \\
\text { Behavior of } \\
\text { Turkish } \\
\text { Financial } \\
\text { Consumers }\end{array}$ & $\begin{array}{l}\text { Nurdan } \\
\text { SEVIM, } \\
\text { Özlem } \\
\text { SAYILIR, } \\
\text { Fatih } \\
\text { TEMIZEL }\end{array}$ & 2012 & $\begin{array}{c}\text { International } \\
\text { Journal of } \\
\text { Consumer } \\
\text { Studies }\end{array}$ & $\begin{array}{l}\text { Çalışma finansal } \\
\text { tüketicilerin } \\
\text { finansal } \\
\text { okuryazarlığın } \\
\text { borçlanma } \\
\text { davranışı } \\
\text { üzerindeki etkisini } \\
\text { araştırmaktır. }\end{array}$ & $\begin{array}{l}\text { Çalışmaya } 550 \text { kişi katılmıştır. } \\
\text { Finansal okuryazarlığ y yüksek } \\
\text { finansal tüketicilerin gereğinden } \\
\text { fazla borç alma davranışının daha } \\
\text { az olduğu ve daha etkili kredi } \\
\text { kullanma davranışlarının olduğu } \\
\text { tespit edilmiştir. }\end{array}$ \\
\hline $\begin{array}{l}\text { Ekonomi Okur } \\
\text { Yazarlığına } \\
\text { Yönelik } \\
\text { Ampirik Bir } \\
\text { Araştırma }\end{array}$ & $\begin{array}{c}\text { Nuray } \\
\text { MERCAN } \\
, \\
\text { Emine } \\
\text { OYUR, } \\
\text { Ayşenur } \\
\text { ALTINAY } \\
, \\
\text { Yaşar } \\
\text { AKSANY } \\
\text { AR }\end{array}$ & 2012 & $\begin{array}{c}\text { Ekonomi } \\
\text { Bilimleri } \\
\text { Dergisi }\end{array}$ & $\begin{array}{l}\text { Çalışmada } \\
\text { okuryazarlı ve } \\
\text { eğitim seviyesi ile } \\
\text { ekonomik } \\
\text { rasyonellik ve } \\
\text { bilinç arasındaki } \\
\text { ilişki } \\
\text { incelenmiştir. }\end{array}$ & 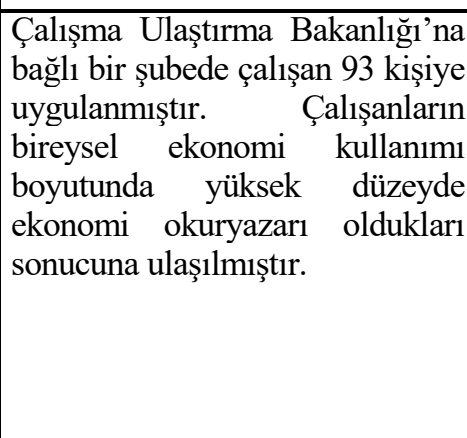 \\
\hline $\begin{array}{l}\text { Financial } \\
\text { Literacy and } \\
\text { Consumer } \\
\text { Credit } \\
\text { Portfolios }\end{array}$ & $\begin{array}{l}\text { Richard } \\
\text { DISNEY, } \\
\text { John } \\
\text { GATHER } \\
\text { GOOD }\end{array}$ & 2013 & $\begin{array}{c}\text { Journal of } \\
\text { Banking \& } \\
\text { Finance }\end{array}$ & $\begin{array}{l}\text { Çalışmanın amacı } \\
\text { finansal } \\
\text { okuryazarlık ve } \\
\text { tüketici kredisi } \\
\text { portföyleri } \\
\text { arasındaki ilişkiyi } \\
\text { incelemektir. }\end{array}$ & $\begin{array}{l}\text { Çalışmaya } 3.037 \text { kişi katılmıştır. } \\
\text { Çalışma sonucunda tüketici } \\
\text { kredisi kullanan bireylerin } \\
\text { tüketici kredisi kullanmayan } \\
\text { bireylere göre daha düşük } \\
\text { finansal okuryazarlık seviyesine } \\
\text { sahip olduğu tespit edilmiștir. }\end{array}$ \\
\hline $\begin{array}{l}\text { Financial } \\
\text { Literacy } \\
\text { Training as A } \\
\text { Strategic } \\
\text { Management } \\
\text { Tool among } \\
\text { Small - } \\
\text { Medium Sized } \\
\text { Businesses } \\
\text { Operating in } \\
\text { Turkey }\end{array}$ & $\begin{array}{c}\text { Ali } \\
\text { BAYRAK } \\
\text { DAROĞL } \\
\text { U, } \\
\text { Firat } \\
\text { Botan } \\
\text { ŞAN }\end{array}$ & 2014 & $\begin{array}{c}\text { Procedia- } \\
\text { Social and } \\
\text { Behavioral } \\
\text { Sciences }\end{array}$ & $\begin{array}{l}\text { Çalışma } \\
\text { Türkiye'de } \\
\text { faaliyet gösteren } \\
\text { küçük ve orta } \\
\text { ölçekli işletme } \\
\text { yöneticilerinin } \\
\text { finansal piyasa } \\
\text { araçlarını } \\
\text { kullanma } \\
\text { becerileri } \\
\text { almaktadır. ele }\end{array}$ & $\begin{array}{lrr}\text { Çalışmaya } & 120 & \text { yönetici } \\
\text { katılmıştır. Çalışma } & \text { sonucunda } \\
\text { yöneticilerin } & \text { finansal } \\
\text { okuryazarlık düzeylerinin yüksek } \\
\text { olduğu tespit edilmiştir. }\end{array}$ \\
\hline $\begin{array}{l}\text { Finansal } \\
\text { Okuryazarlık } \\
\text { ve Para } \\
\text { Yönetimi: } \\
\text { Süleyman } \\
\text { Demirel } \\
\text { Üniversitesi } \\
\text { Akademik } \\
\text { Personel } \\
\text { Üzerine Bir } \\
\text { Uygulama }\end{array}$ & $\begin{array}{l}\text { Elvan } \\
\text { ÖZTÜRK, } \\
\text { Yusuf } \\
\text { DEMIR }\end{array}$ & 2015 & $\begin{array}{l}\text { Muhasebe } \\
\text { ve } \\
\text { Finansman } \\
\text { Dergisi }\end{array}$ & $\begin{array}{l}\text { Çalışmada } \\
\text { Süleyman Demirel } \\
\text { Üniversitesi } \\
\text { akademik } \\
\text { personelinin } \\
\text { finansal } \\
\text { okuryazarlık ve } \\
\text { para yönetimi } \\
\text { konularında } \\
\text { finansal bilgileri, } \\
\text { finansal } \\
\text { davranışları ve } \\
\text { finansal tutumları } \\
\text { incelenmiştir. }\end{array}$ & $\begin{array}{lrr}\text { Çalışmaya } & 299 & \text { akademik } \\
\text { personel katılmıştır. } & \text { Çalışma } \\
\text { sonucunda, Süleyman } & \text { Demirel } \\
\text { Üniversitesi } & \text { akademik } \\
\text { personelinin } \% 82,8 \quad \text { finansal } \\
\text { okuryazar bireyler olduğu ancak } \\
\text { finansal eğitime ihtiyaç } \\
\text { duydukları tespit edilmiştir. }\end{array}$ \\
\hline $\begin{array}{l}\text { Akademik } \\
\text { Personelin } \\
\text { Finansal } \\
\text { Gönenc Hâli }\end{array}$ & $\begin{array}{l}\text { Seyfettin } \\
\text { ÜNAL, }\end{array}$ & 2015 & $\begin{array}{c}\text { Ekonomik } \\
\text { ve Sosyal } \\
\text { Araştırmalar } \\
\text { Dergisi }\end{array}$ & $\begin{array}{l}\text { Çalışmanın amacı, } \\
\text { Dumlupınar } \\
\text { Üniversitesi } \\
\text { akademik }\end{array}$ & $\begin{array}{lcr}\text { Çalışmaya } & 246 & \text { akademik } \\
\text { personel } & \text { katılmıştır. } & \text { Çalışma } \\
\text { sonucunda } & \text { çalışmaya } & \text { katılan } \\
\text { akademik } & \text { personelin } & \text { finansal }\end{array}$ \\
\hline
\end{tabular}


Tablo 1 (Devamı)

Finansal Okuryazarlığı Konu Alan Çalışmalar

\begin{tabular}{|c|c|c|c|c|c|}
\hline Yayının Ad 1 & Yazar(lar)1 & Y1li & $\begin{array}{c}\text { Yayınlandığı } \\
\text { / Sunulduğu } \\
\text { Yer }\end{array}$ & Çalışmanın Amacı & Edinilen Bulgular \\
\hline $\begin{array}{l}\text { Finansal } \\
\text { Okuryazarlık: } \\
\text { Osmaniye } \\
\text { Korkut Ata } \\
\text { Üniversitesi } \\
\text { Personeli } \\
\text { Üzerinde Bir } \\
\text { Araştırma }\end{array}$ & $\begin{array}{l}\text { Mehmet Murat } \\
\text { GUTNU, } \\
\text { Mehmet } \\
\text { CİHANGIR }\end{array}$ & 2015 & $\begin{array}{c}\text { Akademik } \\
\text { Sosyal } \\
\text { Araştırmalar } \\
\text { Dergisi }\end{array}$ & $\begin{array}{l}\text { Çalışmada, } \\
\text { Osmaniye Korkut } \\
\text { Ata Üniversitesinde } \\
\text { çalışan akademik ve } \\
\text { idari personelin } \\
\text { finansal } \\
\text { okuryazarlık } \\
\text { düzeyinin tespit } \\
\text { edilmesi } \\
\text { amaçlanmaktadır } \\
\end{array}$ & $\begin{array}{l}\text { Çalışmaya } 144 \text { personel katılmıştır. } \\
\text { Çalışmada katılımcların } \\
\text { çoğunluğunun Dünyadaki ve } \\
\text { Türkiye'deki ekonomik ve finansal } \\
\text { gelişmelerle ilgilendiği, internet } \\
\text { bankacılığını kullanma, kredi kartı } \\
\text { aylık ortalama faiz oranı bilme ve } \\
\text { kredi kartı hesap ekstresini anlama } \\
\text { seviyesinin yüksek düzeyde olduğu } \\
\text { tespit edilmiştir. }\end{array}$ \\
\hline $\begin{array}{l}\text { Hane Halkının } \\
\text { Finans Eğitimi } \\
\text { ve Finansal } \\
\text { Okuryazarlık } \\
\text { Düzeyleri } \\
\text { Üzerine } \\
\text { Kocaeli'nde } \\
\text { Bir Araştırma }\end{array}$ & $\begin{array}{c}\text { Sibel } \\
\text { FETTAHOĞLU }\end{array}$ & 2015 & $\begin{array}{l}\text { Muhasebe } \\
\text { ve } \\
\text { Finansman } \\
\text { Dergisi }\end{array}$ & $\begin{array}{l}\text { Çalışmanın amacı } \\
\text { Kocaeli'nde ikamet } \\
\text { eden kişilerin } \\
\text { finansal } \\
\text { okuryazarlık } \\
\text { düzeylerinin } \\
\text { belirlenmesi ve hane } \\
\text { halkının aile } \\
\text { bütçesinin yönetimi } \\
\text { konusunda bilgi ve } \\
\text { davranıslarının } \\
\text { belirlenmesidir. }\end{array}$ & $\begin{array}{l}\text { Çalışmaya } 83 \text { kişi katılmıştır. } \\
\text { Çalışma sonucunda katılımcıların } \\
\text { finansal okuryazarlık konusunda } \\
\text { temel düzeyde bilgilerinin olduğu } \\
\text { ancak karmaşık ve bilgiyi } \\
\text { gerektiren araç, ürün ve teknikler } \\
\text { konusunda yetersiz oldukları; } \\
\text { ayrıca hane halkının yatırım } \\
\text { araçlarını tanıma ve yatırım } \\
\text { konularında bilgilerinin eksik } \\
\text { olduğu tespit edilmiştir. }\end{array}$ \\
\hline $\begin{array}{l}\text { Finansal } \\
\text { Okuryazarlık } \\
\text { Düzeyinin } \\
\text { Belirlenmesi: } \\
\text { Türk Silahlı } \\
\text { Kuvvetleri } \\
\text { Emekli } \\
\text { Personeli } \\
\text { Üzerinde Bir } \\
\text { Araştırma } \\
\end{array}$ & $\begin{array}{c}\text { Yusuf KADERLİ, } \\
\text { Umü Tolga } \\
\text { GÜMÜŞ, } \\
\text { Emre DANIŞMAN }\end{array}$ & 2016 & $\begin{array}{l}\text { International } \\
\text { Journal of } \\
\text { Finance \& } \\
\text { Banking } \\
\text { Studies }\end{array}$ & \begin{tabular}{|l|} 
Çalışmanın amacı; \\
Türkiye'deki emekli \\
olmuş askeri \\
personelin finansal \\
okuryazarlık \\
seviyesini \\
belirlemektir.
\end{tabular} & $\begin{array}{l}\text { Çalışma } 250 \text { kişiye uygulanmıştır. } \\
\text { Çalışma sonucunda finansal } \\
\text { okuryazarlık becerisinin emekli } \\
\text { Türk Silahlı Kuvvetleri bireylerinin } \\
\text { büyük çoğunluğunda yeterli } \\
\text { olmadığı tespit edilmiştir. }\end{array}$ \\
\hline $\begin{array}{l}\text { Türkiye'deki } \\
\text { Finansal } \\
\text { Okuryazarlığı } \\
\text { n ve Finansal } \\
\text { Farkındalığın } \\
\text { Durumu }\end{array}$ & $\begin{array}{c}\text { Mahmut } \\
\text { YARDIMCIÖĞLU, } \\
\text { Ali YÖRÜK }\end{array}$ & 2016 & $\begin{array}{l}\text { Muhasebe } \\
\text { ve Vergi } \\
\text { Uygulamalar } \\
1 \text { Dergisi }\end{array}$ & \begin{tabular}{|l|} 
Çalışmanın amacı \\
Kahramanmaraş’ta \\
çalışan bireylerin \\
finansal farkındalık \\
ile finansal \\
okuryazarlık \\
durumları ilişkiyi \\
arasındaki \\
incelemektir. \\
\end{tabular} & $\begin{array}{l}\text { Çalışma } 324 \text { kişiye uygulanmıştır. } \\
\text { Çalışanların finansal farkındalıkları } \\
\text { arttıķa finansal okuryazarlıklarının } \\
\text { da arttığı yönünde bulgular elde } \\
\text { edilmiştir. }\end{array}$ \\
\hline $\begin{array}{l}\text { Finansal } \\
\text { Okuryazarlık: } \\
\text { Hanehalkı } \\
\text { Üzerine Bir } \\
\text { Araştırma }\end{array}$ & $\begin{array}{c}\text { Emine GULER, } \\
\text { Hakan TUNAHAN }\end{array}$ & 2017 & $\begin{array}{l}\text { Işletme } \\
\text { Bilimi } \\
\text { Dergisi }\end{array}$ & $\begin{array}{l}\text { Çalışmanın amacı } \\
\text { Sakarya } \\
\text { hanehalkının } \\
\text { finansal } \\
\text { okuryazarlık } \\
\text { düzeyinin } \\
\text { belirlenmesi ve } \\
\text { demografik } \\
\text { özelliklerin finansal } \\
\text { okuryazarlık } \\
\text { düzeyine etkisinin } \\
\text { incelenmesidir. }\end{array}$ & $\begin{array}{l}\text { Çalışmaya } 453 \text { kişi katılmıştır. } \\
\text { Çalışma sonucunda hanehalkı̈ın } \\
\text { yarısından fazlasının düşük } \\
\text { düzeyde finansal okuryazar olduğu, } \\
\text { finansal okuryazarlık düzeyi ile } \\
\text { demografik özellikler ve tasarruf } \\
\text { davranışı arasında anlamlı ilişki } \\
\text { olduğu tespit edilmiştir. }\end{array}$ \\
\hline
\end{tabular}


Tablo 1 (Devamı)

Finansal Okuryazarlığı Konu Alan Çalışmalar

\begin{tabular}{|c|c|c|c|c|c|}
\hline Yayının Adı & Yazar(lar)1 & Yilı & $\begin{array}{c}\text { Yayınlandiğı / } \\
\text { Sunulduğu } \\
\text { Yer }\end{array}$ & Çalışmanın Amacı & Edinilen Bulgular \\
\hline $\begin{array}{l}\text { Finansal } \\
\text { Okuryazarlık } \\
\text { ve Tasarruf } \\
\text { Davranışları: } \\
\text { Kamu } \\
\text { Çalışanları } \\
\text { Üzerine Bir } \\
\text { İnceleme }\end{array}$ & $\begin{array}{l}\text { Metehan ŞAHIN, } \\
\text { Serap BARIŞ }\end{array}$ & 2017 & $\begin{array}{c}\text { Çankırı } \\
\text { Karatekin } \\
\text { Üniversitesi } \\
\text { İktisadi ve } \\
\text { İdari Bilimler } \\
\text { Dergisi }\end{array}$ & $\begin{array}{l}\text { Çalışma Tokat ili } \\
\text { kamu çalışanlarının } \\
\text { finansal okuryazarlık } \\
\text { seviyeleri ve finansal } \\
\text { okuryazarlık } \\
\text { seviyelerinin tasarruf } \\
\text { davranışları üzerinde } \\
\text { anlamlı bir etkisinin } \\
\text { olup olmadığını } \\
\text { incelemektir. } \\
\end{array}$ & $\begin{array}{l}\text { Çalışma } 427 \text { kamu çalışanına } \\
\text { uygulanmıştır. Çalışma sonucunda } \\
\text { yaş, hanehalkı geliri, finansal } \\
\text { gelişmeleri takip etme durumu ve } \\
\text { temel/ileri düzey finansal } \\
\text { okuryazar olma kamu çalışanlarının } \\
\text { tasarruf davranışı üzerinde anlamlı } \\
\text { pozitif etkiye sahip olduğu tespit } \\
\text { edilmiştir. }\end{array}$ \\
\hline $\begin{array}{l}\text { A Baseline } \\
\text { Investigation } \\
\text { of Financial } \\
\text { Literacy } \\
\text { Levels: The } \\
\text { Case } \\
\text { Kayseri } \\
\text { Province }\end{array}$ & $\begin{array}{c}\text { Semra AKSOYLU, } \\
\text { Derviş } \\
\text { BOZTOSUN, } \\
\text { Fatih ALTINIŞIK, } \\
\text { Emre Hayri } \\
\text { BARAZ }\end{array}$ & 2017 & $\begin{array}{l}\text { Muhasebe ve } \\
\text { Finansman } \\
\text { Dergisi }\end{array}$ & $\begin{array}{|lr|}\text { Çalışma } & \text { Kayseri } \\
\text { ilinde } & \text { yaşayan } \\
\text { bireylerin } & \text { finansal } \\
\text { okuryazarlık } & \\
\text { düzeylerini ve finansal } \\
\text { okuryazarlıkları ile } \\
\text { demografik } & \text { özellikler } \\
\text { arasındaki } & \text { ilişkiyi } \\
\text { incelemektedir. } \\
\end{array}$ & $\begin{array}{l}\text { Çalışma } 400 \text { kişiye uygulanmıştır. } \\
\text { Çalışma sonucunda bireylerin } \\
\text { ödenen faiz ve paranın zaman } \\
\text { değeri gibi bazı temel finansal } \\
\text { konular hakkında bilgi sahibi } \\
\text { olmalarına karşın yeterli düzeyde } \\
\text { finansal okuryazar olmadıkları } \\
\text { tespit edilmiştir. }\end{array}$ \\
\hline $\begin{array}{l}\text { Sağlık } \\
\text { Bakanlığına } \\
\text { Bağlı } \\
\text { Hastanelerde } \\
\text { Çalışan Sağlık } \\
\text { Personelinin } \\
\text { Finansal } \\
\text { Okuryazarlık } \\
\text { Düzeyinin } \\
\text { Belirlenmesi: } \\
\text { Sivas İli } \\
\text { Örneği } \\
\end{array}$ & $\begin{array}{c}\text { Fatih ALTAN, } \\
\text { Baha BIÇER }\end{array}$ & 2017 & $\begin{array}{l}\text { Business \& } \\
\text { Management } \\
\text { Studies: An } \\
\text { International } \\
\text { Journal }\end{array}$ & $\begin{array}{l}\text { Çalışmanın amacı } \\
\text { Sivas ili rağlık } \\
\text { çalışanlarının finansal } \\
\text { okuryazarlık düzeyini } \\
\text { belirlemektir. }\end{array}$ & $\begin{array}{l}\text { Çalışma } 338 \text { kişiye uygulanmıştır. } \\
\text { Çalışma sonucunda finansal } \\
\text { okuryazarlık başarı puanı \%60 } \\
\text { olarak belirlenmiştir. Sağlık } \\
\text { çalışanlarının en fazla bilgiye sahip } \\
\text { olduğu alan emeklilik ve } \\
\text { sigortacılık iken, en az bilgiye sahip } \\
\text { olduğu alan yatırım konusu } \\
\text { olmuştur. Ayrıca finansal gündeme } \\
\text { ilişkin bilgilerinin az olduğu tespit } \\
\text { edilmiştir. }\end{array}$ \\
\hline $\begin{array}{l}\text { Dumlupınar } \\
\text { Üniversitesi } \\
\text { Akademik } \\
\text { Personelinin } \\
\text { Finansal } \\
\text { Okuryazarlık } \\
\text { Düzeyi } \\
\text { Üzerine Bir } \\
\text { Araştırma }\end{array}$ & $\begin{array}{c}\text { Hakan ÇELİKKOL, } \\
\text { Mediha M. } \\
\text { ÇELİKKOL, } \\
\text { Nasıf ÖZKAN }\end{array}$ & 2017 & $\begin{array}{l}\text { MANAS } \\
\text { Sosyal } \\
\text { Araştırmalar } \\
\text { Dergisi }\end{array}$ & \begin{tabular}{|l|} 
Çalışmada, \\
Dumlupınar \\
Üniversitesi akademik \\
personelinin finansal \\
okuryazarlık düzeyi \\
belirlenmeye \\
çalışılmıştır.
\end{tabular} & \begin{tabular}{|lrr} 
Çalışmaya & 505 kişi & katılmıştır. \\
Çalışmada & kendini & finansal \\
okuryazar olarak nitelendiren & olak \\
akademisyenlerin 51 'inin & aslında \\
finansal okuryazar & olarak \\
değerlendirilemeyeceği, & kendini \\
finansal okuryazar & olarak \\
nitelendirmeyen akademisyenlerin \\
24'ünün ise aslında & finansal \\
okuryazar & olarak \\
değerlendirilebileceği & tespit \\
edilmiștir. & \\
\end{tabular} \\
\hline
\end{tabular}


Tablo 1 (Devamı)

Finansal Okuryazarlığı Konu Alan Çalışmalar

\begin{tabular}{|c|c|c|c|c|c|}
\hline Yayının Adı & Yazar(lar)1 & Y1lı & $\begin{array}{l}\text { Yayınlandığı / } \\
\text { Sunulduğu Yer }\end{array}$ & $\begin{array}{c}\text { Çalışmanın } \\
\text { Amacı }\end{array}$ & Edinilen Bulgular \\
\hline $\begin{array}{l}\text { Akademik } \\
\text { Gelişim ve } \\
\text { Finansal } \\
\text { Okuryazarlık } \\
\text { Arasındaki } \\
\text { İlişkinin Tespiti } \\
\text { Üzerine Bir } \\
\text { Araştırma }\end{array}$ & $\begin{array}{c}\text { Sedat } \\
\text { DURMUŞKAYA, } \\
\text { Yusuf B. KAVAS }\end{array}$ & 2018 & $\begin{array}{l}\text { Yönetim ve } \\
\text { Ekonomi }\end{array}$ & $\begin{array}{l}\text { Çalışmanın } \\
\text { amacı Marmara } \\
\text { Bölgesi'nde } \\
\text { bulunan çeşitli } \\
\text { üniversitelerin } \\
\text { akademik } \\
\text { personelinin } \\
\text { finansal } \\
\text { okuryazarlık } \\
\text { düzeylerinin } \\
\text { tespit } \\
\text { edilmesidir. }\end{array}$ & $\begin{array}{l}\text { Çalışmaya } 415 \text { akademik } \\
\text { personel } \\
\text { Araştırmada katılmıştır. } \\
\text { akademisyenlerin } \\
\text { kadınlardan, sosyal bilimler } \\
\text { alanında çalışan } \\
\text { akademisyenlerin sağlık } \\
\text { bilimlerinde çalışanlardan, } \\
\text { lisansüstü mezunu olan } \\
\text { akademisyenlerin lisans } \\
\text { mezunu olanlardan, öğretim } \\
\text { görevlisi ve öğretim üyesi } \\
\text { olan akademisyenlerin } \\
\text { araştırma görevlisi } \\
\text { olanlardan finansal açıdan } \\
\text { daha okuryazar olduğu } \\
\text { sonucuna ulaşılmıştır. } \\
\text { Ayrıca akademisyenlerin } \\
\text { yaşları arttıkça finansal } \\
\text { okuryazarlı düzeylerinin } \\
\text { artmakta olduğu tespit } \\
\text { edilmiştir. }\end{array}$ \\
\hline $\begin{array}{l}\text { Finansal } \\
\text { Okuryazarlık: } \\
\text { Ağrı Esnaf ve } \\
\text { Sanatkârlarına } \\
\text { Yönelik Bir } \\
\text { Araştırma }\end{array}$ & $\begin{array}{c}\text { Selami GÜNEY, } \\
\text { Halil TANYILDIZI }\end{array}$ & 2018 & $\begin{array}{l}\text { Econharran } \\
\text { Harran } \\
\text { Üniversitesi } \\
\text { İİBF Dergisi }\end{array}$ & $\begin{array}{l}\text { Çalışmanın } \\
\text { amacı Ağrı esnaf } \\
\text { ve sanatkarlarının } \\
\text { finansal } \\
\text { okuryazarlığının } \\
\text { tespit } \\
\text { edilmesidir. }\end{array}$ & 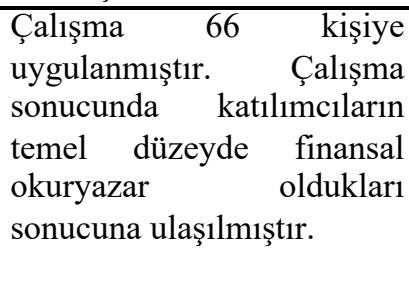 \\
\hline $\begin{array}{l}\text { Yöneticilerin } \\
\text { Finansal } \\
\text { Okuryazarlık } \\
\text { Düzeylerinin } \\
\text { Belirlenmesi: } \\
\text { Bişkek Örneği }\end{array}$ & $\begin{array}{c}\text { Celaleddin } \\
\text { SERİNKAN, } \\
\text { Mahmut ERDOĞAN }\end{array}$ & 2018 & $\begin{array}{l}\text { 1. Uluslararası } \\
\text { Ekonomi ve } \\
\text { İşletme } \\
\text { Sempozyumu }\end{array}$ & $\begin{array}{l}\text { Çalışmanın } \\
\text { amacı, Bişkek } \\
\text { şehrinde faaliyet } \\
\text { gösteren işletme } \\
\text { yöneticilerinin } \\
\text { finansal } \\
\text { okuryazarlık } \\
\text { düzeylerinin } \\
\text { belirlenmesidir. }\end{array}$ & \begin{tabular}{llr} 
Çalışmaya 50 & yönetici \\
katılmıştır. & \multicolumn{2}{c}{ Çalışma } \\
sonucunda işletme & eğitimi \\
alan yöneticilerin & daha \\
yüksek finansal bilgi & beviyesine sahip oldukları \\
seviye & tespit edilmiştir.
\end{tabular} \\
\hline $\begin{array}{l}\text { Kütahya İlinde } \\
\text { Bulunan Özel } \\
\text { Eğitim } \\
\text { Kurumlarında } \\
\text { Öğrenim Gören } \\
\text { Öğrenci } \\
\text { Velilerinin } \\
\text { Finansal } \\
\text { Okuryazarlık } \\
\text { Düzeylerinin } \\
\text { Belirlenmesi }\end{array}$ & Dursun BOZ & 2019 & $\begin{array}{l}\text { Muhasebe ve } \\
\text { Finansman } \\
\text { Dergisi }\end{array}$ & $\begin{array}{l}\text { Çalışmanın } \\
\text { amacı, Kütahya } \\
\text { ili özel eğitim } \\
\text { kurumlarında } \\
\text { öğrenim gören } \\
\text { öğrenci } \\
\text { velilerinin } \\
\text { finansal } \\
\text { okuryazarlık } \\
\text { düzeyini } \\
\text { belirlemektir. }\end{array}$ & $\begin{array}{l}\text { Çalışmaya } 692 \text { veli } \\
\text { katılmıştır. Çalışmaya } \\
\text { katılan velilerin finansal } \\
\text { okuryazarlı düzeylerinin } \\
\text { yüksek olduğu ancak } \\
\text { finansal okuryazarlığın } \\
\text { tutum ve algı alt faktörlerine } \\
\text { katılımın orta seviyede } \\
\text { olduğu belirlemiştir. Ayrıca } \\
\text { finansal okuryazarlık ve } \\
\text { demografik değişkenler } \\
\text { (hanehalkı gelir seviyesi } \\
\text { hariç) arasında anlamlı bir } \\
\text { farklılık } \\
\text { edilememistir. }\end{array}$ \\
\hline
\end{tabular}


Tablo 1 (Devam)

Finansal Okuryazarlığı Konu Alan Çalışmalar

\begin{tabular}{|c|c|c|c|c|c|}
\hline Yayının Adı & Yazar(lar)1 & Yil1 & $\begin{array}{l}\text { Yayınlandığı } \\
\text { / Sunulduğu } \\
\text { Yer }\end{array}$ & $\begin{array}{c}\text { Çalışmanın } \\
\text { Amacı }\end{array}$ & Edinilen Bulgular \\
\hline $\begin{array}{l}\text { Bireysel } \\
\text { Emeklilik } \\
\text { Sistemi } \\
\text { Üyeliği ve } \\
\text { Bazı } \\
\text { Demografik } \\
\text { Değişkenlerin } \\
\text { Finansal } \\
\text { Okuryazarlık } \\
\text { ile İlişkisi }\end{array}$ & $\begin{array}{c}\text { Seyfettin ÜNAL, } \\
\text { Dursun BOZ, } \\
\text { Aykut ATAŞER }\end{array}$ & 2019 & $\begin{array}{c}\text { Sosyal } \\
\text { Bilimler } \\
\text { Metinleri }\end{array}$ & $\begin{array}{l}\text { Çalışmanın } \\
\text { amacı Kütahya il } \\
\text { merkezinde } \\
\text { bulunan banka } \\
\text { çalışanlarının } \\
\text { finansal } \\
\text { okuryazarlık } \\
\text { düzeyleri ile } \\
\text { bireysel } \\
\text { emeklilik } \\
\text { sistemine üyelik } \\
\text { arasındaki } \\
\text { ilişkinin } \\
\text { incelenmesidir. } \\
\end{array}$ & $\begin{array}{l}\text { Çalışmaya Kütahya il merkezinde } \\
\text { bulunan } 17 \text { bankanın } 120 \text { çalışanı } \\
\text { katılmıştır. Banka çalışanlarının } \\
\text { finansal okuryazarlık } \\
\text { düzeylerinin yüksek olduğu tespit } \\
\text { edilmiştir. BES üyelerinin } \\
\text { finansal okuryazarlık konusunda } \\
\text { daha duyarlı oldukları, } \\
\text { çalışanların yaş, eğitim, çalışma } \\
\text { süresi ile finansal okuryazarlık } \\
\text { düzeyi arasıdar anlamlı } \\
\text { farklılıklar olduğu tespit } \\
\text { edilmiştir. }\end{array}$ \\
\hline $\begin{array}{l}\text { Bazı Sosyo- } \\
\text { Demografik } \\
\text { Değişkenler } \\
\text { Açıından } \\
\text { Kamu } \\
\text { Çalışanlarının } \\
\text { Finansal } \\
\text { Okuryazarlık } \\
\text { Düzeylerinin } \\
\text { İncelenmesi }\end{array}$ & $\begin{array}{l}\text { Erhan KILINÇ, } \\
\text { Ali ANTEPLI }\end{array}$ & 2020 & $\begin{array}{c}\text { Selçuk } \\
\text { Üniversitesi } \\
\text { Sosyal } \\
\text { Bilimler } \\
\text { Enstitüsü } \\
\text { Dergisi }\end{array}$ & $\begin{array}{l}\text { Çalışmanın } \\
\text { amacı Konya ili } \\
\text { Beyşehir } \\
\text { ilçesinde görev } \\
\text { yapan kamu } \\
\text { çalışanlarının } \\
\text { bazı sosyo- } \\
\text { demografik } \\
\text { özelliklerine göre } \\
\text { finansal } \\
\text { okuryazarlık } \\
\text { düzeylerinin } \\
\text { incelenmesidir. }\end{array}$ & $\begin{array}{l}\text { Çalışmaya toplam } 203 \text { kamu } \\
\text { çalışanı katılmıştır. Çalışma } \\
\text { sonucunda akademisyen ve } \\
\text { memurların, işçi ve öğretmenlere } \\
\text { nazaran finansal kavramlara } \\
\text { yönelik bilgi düzeylerinin daha } \\
\text { yüksek olduğu, memurların, diğer } \\
\text { kamu kurumu çalışanlarına göre } \\
\text { finansal durumu yönetmede } \\
\text { kendilerini oldukça başarılı } \\
\text { gördükleri; öğretmenlerin diğer } \\
\text { kamu kurumu çalışanlarına göre } \\
\text { düzenli para biriktirmeye daha } \\
\text { yatkın oldukları; işçilerin ise aylık } \\
\text { altın biriktirmeyi daha çok tercih } \\
\text { ettikleri tespit edilmiştir. }\end{array}$ \\
\hline
\end{tabular}

\section{Araştırmanın Yöntemi}

Çalışmanın bu bölümünde araştırmanın amacı, önemi ve kapsamı, sorusu, hipotezleri, karşılaşılan güçlükler, varsayımlar, araştırma yöntemine yer verilmiştir.

\section{Araştırmanın Amacı}

Araştırmanın amacı; bilim insanları arasında finansal okuryazarlık tutum ve davranış ölçeğinin harcama, algı, ilgi ve tutum şeklindeki bileşenleri açısından farklılık olup olmadığını ve çalışma kapsamına dahil edilen bilim insanlarının finansal kavramlara dair bilgi düzeyleri ile tutum ve davranış ölçeğinin bileşenleri arasında ilişki olup olmadığını irdelemektir.

\section{Araştırmanın Önemi ve Kapsamı}

Küreselleşme süreci ve teknolojik alanda yaşanan gelişmeler, finansal ürün ve hizmetlerin çeşitliliğindeki artış, yaşanan finansal krizler gibi finansal olaylar bireylerin finansal konulara olan ilgilerinin yanı sıra finansal okuryazarlığın önemini de arttırmıştır (Antepli ve Kılınç, 2018). Bununla beraber finansal kararların alınmasında, finansal bilginin gerekli olduğu, ancak yeterli olmadığı anlaşılmış; bireylerin finansal bilgiyi kullanabilme becerisinin de önem arz ettiği görülmüştür. Bu durum finansal kavram ve olgulara dair bireysel farkındalığın, finansal okuryazarlığın ve finansal tutum ve davranış becerisinin çeşitli yönlerden sorgulanmasına sebep olmuştur. Literatürde de finansal okuryazarlık üzerine çok sayıda çalışmanın yer aldığı, 
ancak akademisyenler üzerine yapılan çalışmaların sınırlı sayıda olduğu ve hatta akademisyenlerin finansal okuryazarlık tutum ve davranışları özelinde çalışmaya ise rastlanılamadığı görülmüştür. Bu çalışmanın eğitimöğretim alanında üniversitede çalışan akademik personelin finansal okuryazarlık tutum ve davranışlarını saptamaya yönelik bir araştırma olması yönüyle literatüre katkı sağlayacağı düşünülmektedir.

\section{Araştırmanın Soruları}

Araştırma, farklı çalışma alanlarındaki bilim insanlarının finansal okuryazarlık tutum ve davranış ölçeğine göre oluşacak faktörler (harcama, algı, ilgi ve tutum) açısından farklılık arz eden özelliklerini ortaya koymayı hedeflediğinden cevabı aranan sorular aşağıdaki gibi sıralanmıştır:

i.Finansal okuryazarlık tutum ve davranış bileșenleri ile demografik değişkenler arasında anlamlı bir farklılık var midır?

ii.Finansal okuryazarlık tutum ve davranış bileşenleri ile finansal kavramların bilinirliği ile arasında anlamlı bir farklılik var midır?

\section{Araştırmanın Hipotezleri}

Çalışmanın amacı doğrultusunda demografik değişkenlere göre oluşturulan gruplar bakımından test edilecek hipotezler aşağıdaki gibi sıralanmıştır:

H1: Finansal okuryazarlık tutum ve davranış bileşenleri ile demografik değişkenler arasında anlamlı bir farklilik yoktur.

Araştırmaya konu olan H1 hipotezine ait alt hipotezler de katılımcıların demografik özelliklerine göre aşağıdaki şekilde tanımlanmıştır.

H1a $_{0}$ : Finansal okuryazarlık tutum ve davranış bileşenleri ile cinsiyet arasında anlamlı bir farklılık yoktur.

H1b: Finansal okuryazarlık tutum ve davranış bileșenleri ile eğitim durumu arasında anlamlı bir farkllik yoktur.

H1co: Finansal okuryazarlık tutum ve davranış bileşenleri ile çalışılan bilim alanları arasında anlaml bir farklilik yoktur.

H1d: Finansal okuryazarlık tutum ve davranış bileșenleri ile akademik unvan arasında anlamlı bir farklilik yoktur.

H1e: Finansal okuryazarlik tutum ve davranış bileşenleri ile ekonomik gelişmeleri takip etme arasinda anlamlı bir farklılik yoktur.

H1f: Finansal okuryazarlık tutum ve davranış bileșenleri ile aile ortalama geliri arasında anlamlı bir farklilik yoktur.

H1go: Finansal okuryazarlık tutum ve davranış bileşenleri ile yaş durumu arasında anlamlı bir farklilk yoktur.

$H_{1} h_{0}$ : Finansal okuryazarlık tutum ve davranış bileşenleri ile medeni durum arasında anlamlı bir farklilk yoktur.

Finansal kavramların bilinirliği bakımından oluşan gruplar bakımından test edilecek hipotezler de aşağıdaki gibi sıralanmıştır:

H2: Finansal okuryazarlık tutum ve davranış bileșenleri ile finansal kavramların bilinirliği arasında anlaml bir farklillk yoktur. 
Araştırmaya konu olan $\mathrm{H} 2$ hipotezine ait alt hipotezler de aşağıdaki şekilde tanımlanmıştır.

H2a: Finansal okuryazarlı tutum ve davranış bileşenleri ile enflasyon arasında anlamlı bir farklılık yoktur.

$H_{2} \boldsymbol{b}_{0}$ : Finansal okuryazarlik tutum ve davranış bileșenleri ile faiz arasında anlamlı bir farklılık yoktur.

H2co: Finansal okuryazarlık tutum ve davranış bileşenleri ile işsizlik arasında anlamlı bir farklılık yoktur.

H2d $_{0}$ : Finansal okuryazarlık tutum ve davranış bileşenleri ile tasarruf arasında anlamlı bir farklılık yoktur.

H2e: Finansal okuryazarlık tutum ve davranış bileşenleri ile hisse senedi arasında anlamlı bir farklilk yoktur.

H2fo: Finansal okuryazarlık tutum ve davranış bileşenleri ile yatırım fonu arasında anlamlı bir farklilik yoktur.

H2go: Finansal okuryazarlık tutum ve davranış bileşenleri ile döviz arasında anlamlı bir farklılık yoktur.

$H_{2} \boldsymbol{h}_{0}$ : Finansal okuryazarlık tutum ve davranış bileşenleri ile senet arasında anlamlı bir farklılık yoktur.

H21: Finansal okuryazarlık tutum ve davranış bileşenleri ile çek arasında anlamlı bir farklılık yoktur.

H2jo: Finansal okuryazarlık tutum ve davranış bileşenleri ile bireysel emeklilik arasında anlamlı bir farklilık yoktur.

H2k: Finansal okuryazarlık tutum ve davranış bileșenleri ile yatırım arasında anlamlı bir farklılık yoktur.

H21: Finansal okuryazarlık tutum ve davranış bileşenleri ile katılım bankası arasında anlamlı bir farklılik yoktur.

\section{Araştırma Sırasında Karşılaşılan Güçlükler ve Varsayımlar}

Araştırma 2019 yılı eğitim-öğretim döneminin sona erdiği yaz döneminde gerçekleştirilmiştir. Bu durum akademik personele erişime sınır getiren en önemli etken olmuştur. Zira akademik personelin bir kısmının yıllık izin kullandığı, bir kısmının da eğitim-öğretim faaliyetlerinin devam etmiyor oluşu nedeniyle çalışma ofislerini aynı sıklıkla kullanmadıkları gözlenmiştir.

Karşılaşılan bir diğer güçlük de yüz yüze iletişim kurulan akademik personelin araştırmaya olan tutumları olmuştur. Araştırmanın sonucunda finansal açıdan yetersiz görülecekleri konusunda tedirginliklerini dile getirip çalışmaya katılmaktan imtina edenler olmuştur.

\section{Araştırmada Kullanılan Değişkenler}

Araştırmada kullanılan değişkenler bağımlı ve bağımsız değişkenler olmak üzere 2 ana grupta ele alınabilir. Bağımsız değişkenler de kendi içinde demografik değişkenler ve finansal kavramlar şeklinde iki alt gruba ayrilabilir. 


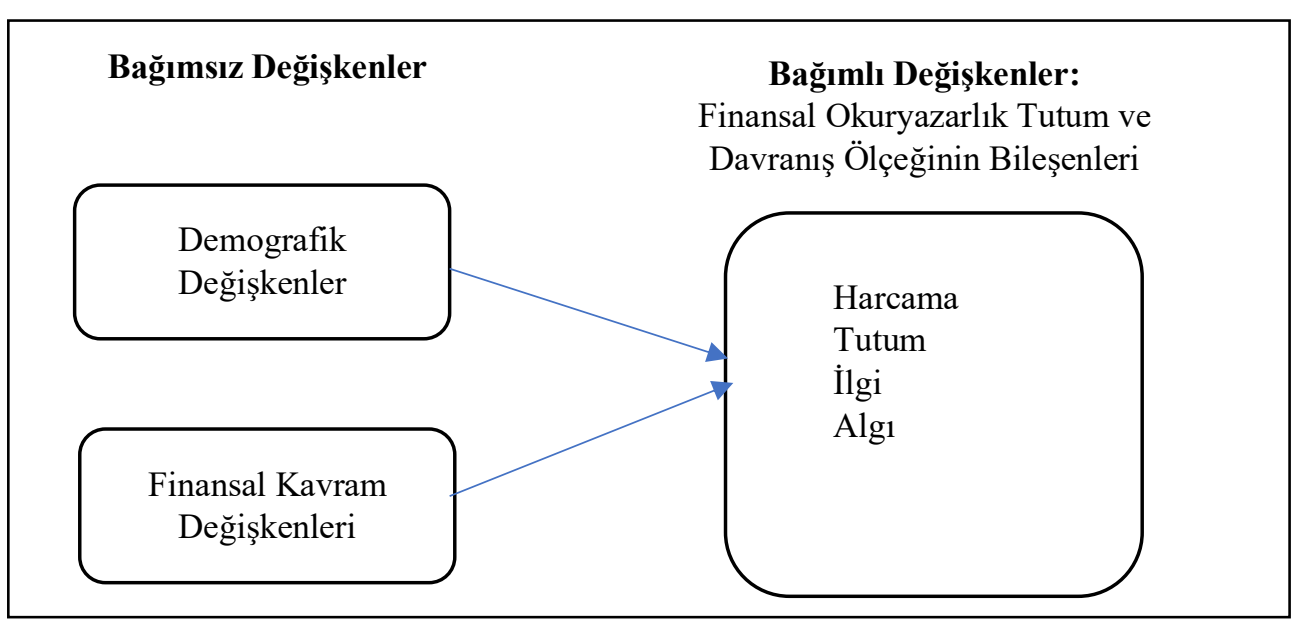

Şekil 1. Değişkenler arasındaki ilişki

Bağımlı değisşkenler; Finansal Okuryazarlık Tutum ve Davranış Ölçeği ile belirlenecek olan harcama, tutum, ilgi ve algi faktörlerinden ibarettir.

Bağımsız değişkenler ise demografik değişkenler ve finansal kavram değişkenleri olmak üzere iki alt gruba ayrılmaktadır. Demografik değişkenler; cinsiyet, medeni durum, eğitim durumu, yaş, unvan, çalışılan bilim alanı, ekonomik gelişmeleri takip edip/etmeme, ailenin ortalama geliri değişkenleridir. Finansal kavram değişkenleri de enflasyon, faiz, işsizlik, döviz, senet, çek, yatırım, tasarruf, hisse senedi, yatırım fonu, katılım bankası, bireysel emeklilik değişkenleridir.

\section{Araştırmanın Evreni ve Örneklemi}

Literatürde yapılan araştırmalarda öğrencilerin, gençlerin, belli meslek gruplarının finansal okuryazarlık durumları incelenmiş, öğrenim seviyesi bakımından en yüksek derece olan doktora derecesine sahip veya bu dereceye talip olan bilim insanlarının göreli olarak daha bilinçli olmaları beklentisi ile finansal okuryazarlık tutum ve davranışları açısından incelenmek istenmiştir. Araştırma evrenini Niğde Ömer Halisdemir Üniversitesi'nde görevli akademisyenler oluşturmaktadır. Anakütle ve örneklemin Niğde Ömer Halisdemir Üniversitesi'nde görevli akademik personelden oluşmasının nedeni, araştırmacıların ikisinin bu üniversitede görevli olmasının veri toplamada kolaylık sağlayacağı düşüncesidir. Yükseköğretim Kurulu Başkanlığı’nın resmi sayfasında ilan olunan istatistiklerden alınan bilgiye göre Niğde Ömer Halisdemir Üniversitesi'nde 951 akademik personelin görev yaptığı belirlenmiştir ${ }^{11}$.

Araştırmada tüm evrene ulaşmanın mümkün olmaması nedeniyle örneklemeye gidilmiştir. Araştırmaya katılan ve geçerli cevap veren 247 kişiden sağlanan geri dönüş; örneklem genişliği bakımından \%95 güven düzeyinde, $\% 5,37$ hata payına karşıllk gelmektedir.

Araştırmada veri toplama araçlarından anket yöntemi kullanılmış ve örneklemede ise kolayda örnekleme yöntemi benimsenmiştir.

\section{Araştırmada Kullanılan Verilerin Toplanması}

Araştırmada veri toplama aracı olarak anket yöntemi kullanılmış ve gönüllülük esasına dayalı olarak araştırmaya katılan akademisyenlerle yüz yüze anket uygulanmasıyla veriler elde edilmiştir.

Araştırmada uygulanan anket formu üç bölümden ve 49 sorudan oluşmaktadır:

\footnotetext{
${ }^{11}$ Araştırmanın anakütlesini oluşturan Niğde Ömer Halisdemir Üniversitesi’nde görevli akademisyenlerin sayısı istatistik.yok.gov.tr ağ sayfasından
} alınmış olup verileri Mart 2019’a aittir. 
- Birinci bölümde, akademik personelin demografik özelliklerinin belirlenmesine yönelik sorular yer almaktadır.

- İkinci bölümde, finansal kavramların bilinilirliğine yönelik sorular yer almakta olup bu sorular, daha önce ulusal ve saygın bir medya kuruluşu tarafindan yapılan araştırmada 16-25 arası gençlerin finansal okuryazarlı̆̆ının tespitine yönelik sorulara farklı enstrüman ve kavramlar ile eklemeler yapılmak suretiyle genişletilmiştir.

- Üçüncü bölümde ise finansal tutum ve davranışların tespitine yönelik önermelere yer verilmiştir. Finansal tutum ve davranışların tespitine yönelik Sarıgül (2015) tarafından geliştirilen ve 21 sorudan oluşan "Finansal Okuryazarlık Tutum ve Davranış Ölçeği” kullanılmıştır.

\section{Araştırmada Başvurulan Analiz Yöntemlerinin Belirlenmesi}

Araştırmanın birinci aşamasında, betimsel istatistiklerden yararlanılarak katılımcı profili ortaya konulmuştur. İkinci aşamada, finansal okuryazarlık tutum ve davranış ölçeğinde yer alan maddelerden birbiriyle alakalı olanları belirlemek ve boyut indirgemesi yapabilmek adına faktör analizi kullanılmıştır. Üçüncü olarak da faktör analizinden elde edilen boyutlarla demografik özellikler arasındaki ilişki varlığını saptayabilmek için parametrik olmayan testlerden yararlanılmıştır.

\section{Araştırma Bulguları}

Çalışmanın bu kısmında katılımcılara ait betimsel istatistiklere ve çalışmada kullanılan ölçeğe dayalı olarak çıkarsamalı istatistik bilgilerine yer verilmiştir.

\section{Katılımcıların Demografik Özelliklerine İlişkin Bulgular}

Betimsel bulgular; ankete katılan bilim insanlarının demografik özelliklerini ortaya koymaktadır. Demografik özellikler başlığı altında incelenen bulgular, katılımcıların cinsiyeti, medeni durumu, yaşı, eğitim durumu, unvanı, çalışılan bilim alanı, aile ortalama geliri ve ekonomik gelişmeleri takip etmeyi içermektedir. 
Tablo 2

Katılımcıların Profiline İlişkin Frekans ve Yüzde Değerleri

\begin{tabular}{|c|c|c|c|c|c|c|c|}
\hline \multicolumn{8}{|c|}{ Katılımcıların Demografik Özellikleri } \\
\hline Özellikler & & $\mathbf{N}$ & $\%$ & Özellikler & & $\mathbf{N}$ & $\%$ \\
\hline \multirow{4}{*}{$\begin{array}{l}\text { Medeni } \\
\text { Durum }\end{array}$} & Hiç Evlenmedi & 52 & 21,05 & \multirow{4}{*}{$\begin{array}{l}\text { Eğitim } \\
\text { Durumu }\end{array}$} & Lisans & 15 & 6,07 \\
\hline & Evli & 186 & 75,30 & & Yüksek Lisans & 80 & 32,39 \\
\hline & Boşanmış & 9 & 3,65 & & Doktora & 152 & 61,54 \\
\hline & Toplam & 247 & 100 & & Toplam & 247 & 100 \\
\hline \multirow[t]{6}{*}{ Yaş } & $20-30$ & 38 & 15,37 & \multirow{6}{*}{$\begin{array}{c}\text { Aile } \\
\text { Ortalama } \\
\text { Geliri }\end{array}$} & $5.000-7.500$ & 84 & 34,01 \\
\hline & $31-40$ & 80 & 32,39 & & $7.501-10.000$ & 72 & 29,15 \\
\hline & $41-50$ & 93 & 37,66 & & $10.001-12.500$ & 44 & 17,81 \\
\hline & $51-60$ & 33 & 13,36 & & $12.501-15.000$ & 34 & 13,77 \\
\hline & 61 ve üzeri & 3 & 1,22 & & $15.001+$ & 13 & 5,26 \\
\hline & Toplam & 247 & 100 & & Toplam & 247 & 100 \\
\hline \multirow{5}{*}{$\begin{array}{l}\text { Çalışılan } \\
\text { Bilim } \\
\text { Alanı }\end{array}$} & Sosyal Bilimler & 142 & 57,49 & \multirow{5}{*}{$\begin{array}{l}\text { Ekonomik } \\
\text { Gelişmeleri } \\
\text { Takip Etme }\end{array}$} & Düzenli takip ederim & 130 & 52,63 \\
\hline & Fen Bilimleri & 92 & 37,25 & & Bazen takip ederim & 86 & 34,82 \\
\hline & Sağlık Bilimleri & 10 & 4,05 & & Nadiren takip ederim & 20 & 8,10 \\
\hline & Yabancı Diller & 3 & 1,21 & & Hayır, takip etmiyorum & 11 & 4,45 \\
\hline & Toplam & 247 & 100 & & Toplam & 247 & 100 \\
\hline \multirow[t]{8}{*}{ Cinsiyet } & Kadın & 92 & 37,20 & \multirow[t]{8}{*}{ Unvan } & Prof. Dr. & 34 & 13,77 \\
\hline & Erkek & 155 & 62,80 & & Doç. Dr. & 42 & 17 \\
\hline & \multirow[t]{6}{*}{ Toplam } & \multirow[t]{6}{*}{247} & \multirow[t]{6}{*}{100} & & Dr. Öğr. Üyesi & 69 & 27,94 \\
\hline & & & & & Arş. Gör. Dr. & 2 & 0,81 \\
\hline & & & & & Öğr. Gör. Dr. & 5 & 2,02 \\
\hline & & & & & Arş. Gör. & 43 & 17,41 \\
\hline & & & & & Öğr. Gör. & 52 & 21,05 \\
\hline & & & & & Toplam & 247 & 100 \\
\hline
\end{tabular}

Tablo 2'ye göre; katılımcıların \%62,8'inin erkek, \%37,20'sinin kadın olduğu, \%75'inin evli olduğu, \%21'inin ise hiç evlenmediği, büyük çoğunluğunun (\%61,54'unun) doktora düzeyinde eğitime sahip olduğu, \%37,66'sının 41-50, \%32,39'unun 31-40 yaş aralığında olduğu belirlenmiştir. Unvanları bakımından incelendiğinde \%27,94'ünün Dr. Öğr. Üyesi, \%17’sinin Doç. Dr. unvanına sahip oldukları, katılımcıların \%21,05’inin öğretim görevlisi ve \%17,41'inin Arş. Gör. olduğu, \%57,49’unun sosyal bilimlerde, \%37,25’inin Fen bilimleri çalışma alanında olduğu görülmektedir. Ekonomik gelişmeleri takip etme bakımından incelendiğinde katılımcıların yarıdan fazlasının $(\% 52,63)$ gelişmeleri düzenli takip ettiği görülmektedir. Ayrıca aile ortalama geliri incelendiğinde \%34,01'inin 5.000- 7.500, \%29,15'inin 7.501-10.000 \%5,26'sının ise 15.000 ve üzeri gelire sahip oldukları görülmektedir.

\section{Finansal Kavramların Bilinirliğine iliş̧kin Bulgular}

Finansal kavramların bilinirliğine yönelik sonuçlar Tablo 3'te sunulmuştur. 
Tablo 3

Finansal Kavramların Bilinirliğine Yönelik İstatistiki Bulgular

\begin{tabular}{|c|c|c|c|c|c|c|c|}
\hline \multicolumn{2}{|c|}{ Finansal Kavramlar } & \multirow{2}{*}{$\begin{array}{l}\mathbf{N} \\
194\end{array}$} & \multirow{2}{*}{$\begin{array}{c}\% \\
78,54\end{array}$} & \multicolumn{2}{|c|}{ Finansal Kavramlar } & \multirow{2}{*}{$\begin{array}{c}\mathbf{N} \\
220\end{array}$} & \multirow{2}{*}{\begin{tabular}{|c|}
$\%$ \\
89,07
\end{tabular}} \\
\hline \multirow{4}{*}{$\begin{array}{l}\text { Enflas- } \\
\text { yon }\end{array}$} & $\begin{array}{l}\text { Tam anlamıla } \\
\text { tanımlayabilirim }\end{array}$ & & & \multirow{4}{*}{ Döviz } & $\begin{array}{l}\text { Tam anlamıla } \\
\text { tanımlayabilirim }\end{array}$ & & \\
\hline & $\begin{array}{l}\text { Ne olduğu hakkında fikrim } \\
\text { var ancak tanımlayamam }\end{array}$ & 50 & 20,24 & & $\begin{array}{l}\text { Ne olduğu hakkında fikrim } \\
\text { var ancak tanımlayamam }\end{array}$ & 25 & 10,12 \\
\hline & Fikrim yok & 3 & 1,22 & & Fikrim yok & 2 & 0,81 \\
\hline & Toplam & 247 & 100 & & Toplam & 247 & 100 \\
\hline \multirow{4}{*}{ Faiz } & $\begin{array}{l}\text { Tam anlamıla } \\
\text { tanımlayabilirim }\end{array}$ & 214 & 86,64 & \multirow{4}{*}{ Senet } & $\begin{array}{l}\text { Tam anlamıla } \\
\text { tanımlayabilirim }\end{array}$ & 169 & 68,42 \\
\hline & $\begin{array}{l}\text { Ne olduğu hakkında fikrim } \\
\text { var ancak tanımlayamam }\end{array}$ & 32 & 12,96 & & $\begin{array}{l}\text { Ne olduğu hakkında fikrim } \\
\text { var ancak tanımlayamam }\end{array}$ & 69 & 27,94 \\
\hline & Fikrim yok & 1 & 0,4 & & Fikrim yok & 9 & 3,64 \\
\hline & Toplam & 247 & 100 & & Toplam & 247 & 100 \\
\hline \multirow{4}{*}{ İşsizlik } & $\begin{array}{l}\text { Tam anlamıla } \\
\text { tanımlayabilirim }\end{array}$ & 226 & 91,50 & \multirow{4}{*}{ Çek } & $\begin{array}{l}\text { Tam anlamiyla } \\
\text { tanımlayabilirim }\end{array}$ & 169 & 68,40 \\
\hline & $\begin{array}{l}\text { Ne olduğu hakkında fikrim } \\
\text { var ancak tanımlayamam }\end{array}$ & 19 & 7,69 & & $\begin{array}{l}\text { Ne olduğu hakkında fikrim } \\
\text { var ancak tanımlayamam }\end{array}$ & 64 & 25,90 \\
\hline & Fikrim yok & 2 & 0,81 & & Fikrim yok & 14 & 5,70 \\
\hline & Toplam & 247 & 100 & & Toplam & 247 & 100 \\
\hline \multirow{4}{*}{ Tasarruf } & $\begin{array}{l}\text { Tam anlamıla } \\
\text { tanımlayabilirim }\end{array}$ & 200 & 80,97 & \multirow{4}{*}{$\begin{array}{l}\text { Bireysel } \\
\text { emeklilik }\end{array}$} & $\begin{array}{l}\text { Tam anlamıla } \\
\text { tanımlayabilirim }\end{array}$ & 178 & 72,07 \\
\hline & $\begin{array}{l}\text { Ne olduğu hakkında fikrim } \\
\text { var ancak tanımlayamam }\end{array}$ & 43 & 17,41 & & $\begin{array}{l}\text { Ne olduğu hakkında fikrim } \\
\text { var ancak tanımlayamam }\end{array}$ & 61 & 24,70 \\
\hline & Fikrim yok & 4 & 1,62 & & Fikrim yok & 8 & 3,23 \\
\hline & Toplam & 247 & 100 & & Toplam & 247 & 100 \\
\hline \multirow{4}{*}{$\begin{array}{l}\text { Hisse } \\
\text { Senedi }\end{array}$} & $\begin{array}{l}\text { Tam anlamıla } \\
\text { tanımlayabilirim }\end{array}$ & 122 & 49,39 & \multirow{4}{*}{ Yatırım } & $\begin{array}{l}\text { Tam anlamıyla } \\
\text { tanımlayabilirim }\end{array}$ & 187 & 75,71 \\
\hline & $\begin{array}{l}\text { Ne olduğu hakkında fikrim } \\
\text { var ancak tanımlayamam }\end{array}$ & 98 & 39,68 & & $\begin{array}{l}\text { Ne olduğu hakkında fikrim } \\
\text { var ancak tanımlayamam }\end{array}$ & 54 & 21,86 \\
\hline & Fikrim yok & 27 & 10,93 & & Fikrim yok & 6 & 2,43 \\
\hline & Toplam & 247 & 100 & & Toplam & 247 & 100 \\
\hline \multirow{4}{*}{$\begin{array}{l}\text { Yatırım } \\
\text { Fonu }\end{array}$} & $\begin{array}{l}\text { Tam anlamıla } \\
\text { tanımlayabilirim }\end{array}$ & 96 & 38,87 & \multirow{4}{*}{$\begin{array}{l}\text { Katılım } \\
\text { Bankası }\end{array}$} & $\begin{array}{l}\text { Tam anlamıyla } \\
\text { tanımlayabilirim }\end{array}$ & 94 & 38,06 \\
\hline & $\begin{array}{l}\text { Ne olduğu hakkında fikrim } \\
\text { var ancak tanımlayamam }\end{array}$ & 115 & 46,56 & & $\begin{array}{l}\text { Ne olduğu hakkında fikrim } \\
\text { var ancak tanımlayamam }\end{array}$ & 111 & 44,94 \\
\hline & Fikrim yok & 36 & 14,57 & & Fikrim yok & 42 & 17 \\
\hline & Toplam & 247 & 100 & & Toplam & 247 & 100 \\
\hline
\end{tabular}

Tablo 3'e göre; bilim insanlarının en yüksek yüzdeler ile enflasyon, faiz, işsizlik, döviz, senet, çek, yatırım, tasarruf ve bireysel emeklilik kavramları; en az yüzdeler ile (\%50'den az) hisse senedi, yatırım fonu ve katılım bankası kavramları hakkında bilgi sahibi oldukları görülmüştür. Genel olarak değerlendirildiğinde ise katılımcıların finansal kavramlara yönelik bilinirlik düzeyinin yüksek olduğu söylenebilmektedir.

\section{Araştırmada Kullanılan Ölçeğe i̇lişkin Bulgular}

Çalışmada daha önceden geçerliği ve güvenirliği gösterilen ölçek kullanılmış olup, çalışllan örnek grubu üzerinden toplanan veriler güvenilirlik analizine tabi tutulduğunda güvenirlilik için hesaplanan Cronbach alfa değeri 0,412 olarak belirlenmiştir. Ekolu ve Quainoo (2019) yaptıkları çalışmada alfa < 0,5 için yaygın kanının, güvenirliğin düşük düzeyde olduğu yönünde görüş bildirmişlerdir ve bu durumun az sayıda sorudan veya 
birden fazla kavram, yapı veya bilgi alanını ölçen maddelerin heterojenliğinden kaynaklı olabileceğini belirtmişlerdir. Ayrıca test katılımcı gruplarının her biri farklı karakteristikler ve özelliklere sahip olduğundan her bir grup için farklı güvenilirlik değerinin elde edilebileceğini belirtmişlerdir.

Finansal okuryazarlık tutum ve davranış ölçeğinde yer alan maddelerin birbiriyle tutarlı olanları bir grupta toplayabilmek ve boyut indirgemesi yapabilmek adına faktör analizi uygulanmıştır.

Toplanan verilerin faktör analizine uygun olduğunu saptayabilmek için Bartlett testi ve Kaiser-Meyer-Olkin Örneklem yeterliği testi kullanılmıştır. Çalışma için Bartlett testinin anlamlılık değeri $p=0,000$ olarak bulunmuş ve bu değerin 0,05 önem düzeyinden küçük olması ve Kaiser-Meyer-Olkin Örneklem yeterliği endeksinin 0,795 olarak hesaplanması ve de bu değerin 1'e yakın olması toplanan verinin faktör analizine geçiş aşamasında analize uygunluğunu göstermiştir.

Tablo 4

Finansal Okuryazarlık Tutum ve Davranış Ölçeği İçin Faktör Analizi Sonucu

\begin{tabular}{|c|c|c|c|c|c|}
\hline & Madde & Harcama & Tutum & İlgi & Alg1 \\
\hline 1 & Paramın nasıl bittiğini anlamam & 0,813 & & & \\
\hline 2 & $\begin{array}{l}\text { Günlük olarak yaşarım ve parasal açıdan yarını } \\
\text { düşünmem }\end{array}$ & 0,745 & & & \\
\hline 3 & Harcamalarımı kontrol etmekte zorlanırım & 0,831 & & & \\
\hline 4 & Para, harcanmak içindir, biriktirmek için değildir & 0,511 & & & \\
\hline 5 & Alışveriş yaparken fiyatları kıyaslarım & & 0,720 & & \\
\hline 6 & $\begin{array}{l}\text { Bir şey satın alırken finansal durumumu dikkate } \\
\text { alırım }\end{array}$ & & 0,816 & & \\
\hline 7 & Faturalarımı zamanında öderim & & 0,529 & & \\
\hline 8 & Haftalık ve aylık harcama planları yaparım & & & 0,454 & \\
\hline 9 & $\begin{array}{l}\text { Gazetelerin ve televizyonların ekonomi ve finans } \\
\text { haberlerini izlerim }\end{array}$ & & & 0,539 & \\
\hline 10 & $\begin{array}{l}\text { Uzun süreli finansal hedeflerime ulaşmak için çaba } \\
\text { gösteririm }\end{array}$ & & & 0,537 & \\
\hline 11 & Finans konularında eğitim almak isterim & & & 0,689 & \\
\hline 12 & Parasal konular uğraşmak zevklidir & & & 0,778 & \\
\hline 13 & $\begin{array}{l}\text { Finansal planlama ve bütçe çok parası olanlar için } \\
\text { gereklidir }\end{array}$ & & & & 0,709 \\
\hline 14 & $\begin{array}{l}\text { Günlük ve haftalık gibi kısa dönemler için harcama } \\
\text { planı yapmak gereksizdir }\end{array}$ & & & & 0,632 \\
\hline 15 & $\begin{array}{l}\mathrm{Ne} \text { yaparsam yapayım finansal durumumda bir } \\
\text { değişiklik olmaz }\end{array}$ & & & & 0,655 \\
\hline 16 & $\begin{array}{l}\text { Beslenme ve barınma gibi temel ihtiyaçlarımın } \\
\text { dışında para harcamaktan hoşlanmam }\end{array}$ & & & & 0,596 \\
\hline & $\%$ Varyans & 27 & 11 & 9 & 8 \\
\hline & $\begin{array}{l}\text { Kaiser-Meyer-Olkin-KMO }=\mathbf{0 , 7 9 7} \\
\text { Bartlett's Küresellik testi } x^{2}=1046,667 \\
\mathbf{p}=\mathbf{0 , 0 0 0}\end{array}$ & \multicolumn{4}{|c|}{$\% 55$} \\
\hline
\end{tabular}

Ankette yer alan bazı maddeler düşük açıklama yüzdesine sahip olduğundan modelden çıkartılmış, çalışılan 16 madde ile analiz sonucunda elde edilen 4 tane bileşenin verideki toplam değişimin \% 55 'ini açıkladığ 1 saptanmıştır. $\mathrm{Bu}$ değer, veri setindeki değişimin yarısının 4 boyut tarafından tanımlanabildiğini göstermektedir. Elde edilen bileşenler harcama, tutum, ilgi ve algi olarak isimlendirilmekte olup, her bir 
bileşende sırasıyla 4 madde, 3 madde, 5 madde ve 4 madde yer almaktadır. Harcama boyutunda yer alan maddeler \%27 ile tek başına, faktörler tarafından açıklanan toplam değişimin yarısını açılamaktadır. Kalan değişim diğer boyutlar tarafindan açılanmakta olup tutum boyutunda yer alan maddeler değişimin yaklaşık \%11'ini, ilgi boyutunda yer alan maddeler değişimin \%9'unu ve algı boyutunda yer alan maddeler ise değişimin $\% 8$ 'ini açıklamaktadır.

\section{Boyutlar ve Demografik Değişkenler Arası İlişkilere Ait Bulgular}

$\mathrm{Bu}$ bölümde sırasıyla cinsiyet, eğitim düzeyi, çalışma alanı, unvan, ekonomik gelişmeleri takip etme, aile ortalama geliri, yaş, medeni durum ve finansal kavram değişkenleri ile finansal okuryazarlık ölçeğinin alt boyutları arasında anlamlı bir ilişki olup olmadığını saptamaya yönelik bulgulara yer verilecektir. Değişkenler ile finansal okuryazarlık ölçeği alt boyutları arasındaki anlamlılık sınamasını belirlemek amacıyla; cinsiyette iki bağımsız grup test edildiği için non-parametrik test olan Mann Whitney U, diğer değişkenlerde bağımsız grup sayısı ikiden fazla olduğu için Kruskal Wallis testi kullanılmıştır.

\section{Cinsiyet ve Boyutlar Arasındaki iliş̧i}

Cinsiyet bakımından katılımcılar kadın ve erkek olmak üzere iki grupta toplanmış olup, finansal okuryazarlık tutum ve davranış ölçeğinin alt boyutları ile bu gruplar arasındaki ilişkinin anlamlılık sınamasına ait sonuçlar Tablo 5’te verilmiştir.

Tablo 5

Cinsiyete Göre Faktörler Arası Anlamllık

\begin{tabular}{|c|c|c|c|c|c|c|}
\hline & Cinsiyet & $\mathbf{N}$ & $\begin{array}{c}\text { Sira } \\
\text { Ortalama }\end{array}$ & $\begin{array}{c}\text { Sira } \\
\text { Toplamı }\end{array}$ & $\begin{array}{c}\text { Mann } \\
\text { Whitney } \\
\text { U }\end{array}$ & $\mathbf{P}$ \\
\hline \multirow[t]{2}{*}{ Harcama } & Erkek & 155 & 126,11 & 19546,50 & \multirow{2}{*}{6803,50} & \multirow{2}{*}{0,548} \\
\hline & Kadın & 92 & 120,45 & 11081,50 & & \\
\hline \multirow[t]{2}{*}{ Tutum } & Erkek & 155 & 124,56 & 19306,50 & \multirow{2}{*}{7043,50} & \multirow{2}{*}{0,873} \\
\hline & Kadın & 92 & 123,06 & 11321,50 & & \\
\hline \multirow[t]{2}{*}{ İlgi } & Erkek & 155 & 108,69 & 16846,50 & \multirow{2}{*}{4756,50} & \multirow{2}{*}{$0,000^{*}$} \\
\hline & Kadın & 92 & 149,80 & 13781,50 & & \\
\hline \multirow[t]{2}{*}{ Alg1 } & Erkek & 155 & 136,46 & 21151,50 & \multirow{2}{*}{5198,50} & \multirow{2}{*}{$0,000^{*}$} \\
\hline & Kadın & 92 & 103,01 & 9476,50 & & \\
\hline
\end{tabular}

*\%5 önem düzeyinde anlaml.

Cinsiyet bakımından test edilecek hipotezler aşağıdaki gibidir:

$H a_{0}$ : Katılımcıların cinsiyeti finansal okuryazarlık ölçeğine ait boyutlara bakış açılarımı etkilememektedir. $H a_{1}$ : Katılımcıların cinsiyeti finansal okuryazarlık ölçeğine ait boyutlara bakış açılarını etkilemektedir.

Katılımcıların cinsiyetinin finansal okuryazarlık boyutlarına bakış açllarında etkili olup olmadığına yönelik yapılan analiz sonucunda dört boyut içinde $\% 5$ önem düzeyinde ilgi $(\mathrm{p}=0,000<0,05)$ ve alg1 $(\mathrm{p}=0,000<0,05)$ alt boyutunda anlamlı bir farklılığın olduğu yani $\mathrm{H}_{\mathrm{o}}$ hipotezinin red edildiği tespit edilmiştir.

\section{Eğitim Düzeyi ve Boyutlar Arasındaki ilişki}

Eğitim düzeyi bakımından katılımcılar lisans, yüksek lisans ve doktora olmak üzere üç grupta toplanmış olup, finansal okuryazarlık ölçeğinin alt boyutları ile bu gruplar arasındaki ilişkinin anlamlılık sınamasına ait sonuçlar Tablo 6'da verilmiştir. 
Tablo 6

Eğitim Düzeyine Göre Faktörler Arası Anlamlılık

\begin{tabular}{|c|c|c|c|c|c|}
\hline & $\begin{array}{l}\text { Eğitim } \\
\text { Durumu }\end{array}$ & $\mathbf{N}$ & Ortalama & Ki-Kare & $\mathbf{P}$ \\
\hline \multirow[t]{3}{*}{ Harcama } & Lisans & 15 & 115,10 & \multirow{3}{*}{1,314} & \multirow{3}{*}{0,518} \\
\hline & Yüksek Lisans & 80 & 117,90 & & \\
\hline & Doktora & 152 & 128,09 & & \\
\hline \multirow[t]{3}{*}{ Tutum } & Lisans & 15 & 109,17 & \multirow{3}{*}{2,046} & \multirow{3}{*}{0,359} \\
\hline & Yüksek Lisans & 80 & 117,43 & & \\
\hline & Doktora & 152 & 128,92 & & \\
\hline \multirow[t]{3}{*}{ İlgi } & Lisans & 15 & 119,50 & \multirow{3}{*}{0,080} & \multirow{3}{*}{0,961} \\
\hline & Yüksek Lisans & 80 & 125,13 & & \\
\hline & Doktora & 152 & 123,85 & & \\
\hline \multirow[t]{3}{*}{ Alg1 } & Lisans & 15 & 125,17 & \multirow{3}{*}{1,377} & \multirow{3}{*}{0,502} \\
\hline & Yüksek Lisans & 80 & 116,35 & & \\
\hline & Doktora & 152 & 127,91 & & \\
\hline
\end{tabular}

Eğitim düzeyi bakımından test edilecek hipotezler aşağıdaki gibidir:

$H b_{o}: \quad$ Katılımcıların eğitim düzeyleri ile finansal okuryazarlık ölçeğine ait boyutlara bakış açıları arasinda anlaml bir fark yoktur.

$H b_{1}:$ Katılımcıların eğitim düzeyleri ile finansal okuryazarlı ölçeğine ait boyutlara bakış açıları arasında anlamlı bir fark vardir.

Tablo incelendiğinde, eğitim düzeyinin harcama, tutum, ilgi ve algıda bir farklılık yaratmadığ saptanmıştır. $\mathrm{H}_{0}$ hipotezi tüm boyutlar için gerek \%5 gerekse $\% 10$ önem düzeyinde red edilememiştir ( $\left.p>0,05 ; p>0,10\right)$. Buna göre, lisans, yüksek lisans ve doktora düzeyinde eğitime sahip bireylerin finansal okuryazarlık alt boyutlarında bakış açılarının farklılaşmadığı söylenebilmektedir.

\section{Çalışılan Bilim Alanı ve Boyutlar Arasındaki ilişki}

Çalışlan bilim alanları; sosyal bilimler, fen bilimleri, sağlık bilimleri ve yabancı diller olmak üzere 4 gruba ayrılmıştır. Bu gruplar ile finansal okuryazarlık ölçeğinin boyutları arasındaki ilişkilerin anlamlılı̆̆ı Tablo 7'de sunulmuştur. 
Tablo 7

Çalışılan Bilim Alanına Göre Faktörler Arası Anlamlılık

\begin{tabular}{|c|c|c|c|c|c|}
\hline & Çalışma Alanı & $\mathbf{N}$ & Ortalama & Ki-Kare & $\mathbf{P}$ \\
\hline \multirow{4}{*}{ Harcama } & Sosyal Bilimler & 142 & 125,57 & \multirow{4}{*}{0,650} & \multirow{4}{*}{0,885} \\
\hline & Fen Bilimleri & 92 & 123,70 & & \\
\hline & Sağlık Bilimleri & 10 & 109,20 & & \\
\hline & Yabancı Diller & 3 & 108,00 & & \\
\hline \multirow[t]{4}{*}{ Tutum } & Sosyal Bilimler & 142 & 121,84 & \multirow{4}{*}{0,904} & \multirow{4}{*}{0,824} \\
\hline & Fen Bilimleri & 92 & 124,99 & & \\
\hline & Sağlık Bilimleri & 10 & 143,20 & & \\
\hline & Yabancı Diller & 3 & 131,67 & & \\
\hline \multirow[t]{4}{*}{ İlgi } & Sosyal Bilimler & 142 & 119,77 & \multirow{4}{*}{1,801} & \multirow{4}{*}{0,615} \\
\hline & Fen Bilimleri & 92 & 131,48 & & \\
\hline & Sağlık Bilimleri & 10 & 121,80 & & \\
\hline & Yabancı Diller & 3 & 102,00 & & \\
\hline \multirow[t]{4}{*}{ Alg1 } & Sosyal Bilimler & 142 & 125,14 & \multirow{4}{*}{1,331} & \multirow{4}{*}{0,722} \\
\hline & Fen Bilimleri & 92 & 124,55 & & \\
\hline & Sağlık Bilimleri & 10 & 99,20 & & \\
\hline & Yabancı Diller & 3 & 136,00 & & \\
\hline
\end{tabular}

Çalışılan bilim alanı bakımından test edilecek hipotezler aşağıdaki gibidir:

$H c_{o}:$ Katılımcıların çalışılan bilim alanı ile finansal okuryazarlık ölçeğine ait boyutlara bakış açıları arasinda anlamlı bir fark yoktur.

Hc $c_{1}$ Katılımcıların çalışılan bilim alanı ile finansal okuryazarlık ölçeğine ait boyutlara bakış açıları arasinda anlamlı bir fark vardir.

Çalışmada yer alan bilim insanlarının çalıştıkları bilim alanı ile finansal okuryazarlık tutum ve davranış bileşenleri arasında anlamlı bir ilişki olup olmadığını sınamak için yapılan analiz sonucunda çalışılan bilim alanının finansal okuryazarlık tutum ve davranış bileşenleri üzerinde istatistiksel olarak anlamlı bir farklılık yaratmadığı tespit edilmiştir. Buna göre $\mathrm{H}_{\mathrm{o}}$ hipotezi finansal okuryazarlık tutum ve davranış bileşenleri ile çalışılan bilim alanları arasında anlamlı bir farklılık yoktur hipotezi reddedilememiştir.

\section{Unvan ve Boyutlar Arasındaki ilişsi}

Unvan bakımından gruplar yedi alt gruptan ibaret olup, gruplara ilişkin veriler Tablo 8'de sunulmuştur. 
Tablo 8

Unvana Göre Faktörler Arası Anlamlılık

\begin{tabular}{|c|c|c|c|c|c|}
\hline & Unvan & $\mathbf{N}$ & Ortalama & Ki-Kare & $\mathbf{P}$ \\
\hline \multirow[t]{7}{*}{ Harcama } & Prof. Dr. & 34 & 141,75 & \multirow{7}{*}{11,004} & \multirow{7}{*}{$0,088^{\star *}$} \\
\hline & Doç. Dr. & 42 & 108,10 & & \\
\hline & Dr. Öğr. Üyesi & 69 & 138,85 & & \\
\hline & Arş. Gör. Dr. & 2 & 137,25 & & \\
\hline & Öğr. Gör. Dr. & 5 & 77,00 & & \\
\hline & Arş. Gör. & 43 & 110,70 & & \\
\hline & Öğr. Gör. & 52 & 120,55 & & \\
\hline \multirow[t]{7}{*}{ Tutum } & Prof. Dr. & 34 & 139,22 & \multirow{7}{*}{13,250} & \multirow{7}{*}{$0,039^{*}$} \\
\hline & Doç. Dr. & 42 & 134,93 & & \\
\hline & Dr. Öğr. Üyesi & 69 & 127,63 & & \\
\hline & Arş. Gör. Dr. & 2 & 46,75 & & \\
\hline & Öğr. Gör. Dr. & 5 & 41,80 & & \\
\hline & Arş. Gör. & 43 & 123,72 & & \\
\hline & Öğrr. Gör. & 52 & 111,51 & & \\
\hline \multirow[t]{7}{*}{ İlgi } & Prof. Dr. & 34 & 107,19 & \multirow{7}{*}{3,516} & \multirow{7}{*}{0,742} \\
\hline & Doç. Dr. & 42 & 127,24 & & \\
\hline & Dr. Öğr. Üyesi & 69 & 127,83 & & \\
\hline & Arş. Gör. Dr. & 2 & 158,25 & & \\
\hline & Öğr. Gör. Dr. & 5 & 102,60 & & \\
\hline & Arş. Gör. & 43 & 130,98 & & \\
\hline & Öğr. Gör. & 52 & 122,26 & & \\
\hline \multirow[t]{7}{*}{ Alg1 } & Prof. Dr. & 34 & 142,87 & \multirow{7}{*}{10,046} & \multirow{7}{*}{0,123} \\
\hline & Doç. Dr. & 42 & 137,12 & & \\
\hline & Dr. Öğr. Üyesi & 69 & 119,43 & & \\
\hline & Arş. Gör. Dr. & 2 & 87,75 & & \\
\hline & Öğr. Gör. Dr. & 5 & 102,00 & & \\
\hline & Arş. Gör. & 43 & 100,58 & & \\
\hline & Öğr. Gör. & 52 & 130,01 & & \\
\hline
\end{tabular}

* \%5 önem düzeyinde anlaml.

* \% 10 önem düzeyinde anlaml.

Unvan bakımından test edilecek hipotezler aşağıdaki gibidir:

$H d_{o}$ : Katılımcıların unvanı finansal okuryazarlık ölçeğine ait boyutlara bakış açılarını etkilememektedir. $H d_{1}$ : Katılımcıların unvanı finansal okuryazarlık ölçeğine ait boyutlara bakış açılarını etkilemektedir.

Katılımcıların sahip olduğu unvanların finansal okuryazarlık boyutlarına bakış açılarında etkili olup olmadığına yönelik yapılan analiz sonucunda \%5 önem düzeyinde tutum boyutunda $(\mathrm{p}=0,039<0,05)$ anlamlı bir farklılık olduğu yani $\mathrm{H}_{\mathrm{o}}$ hipotezinin red edildiği ve \%10 önem düzeyinde harcama boyutunda $(\mathrm{p}=0,088<0,10)$ anlamlı bir farklıllı̆̆n olduğu yani $\mathrm{H}_{\mathrm{o}}$ hipotezinin red edildiği tespit edilmiştir.

\section{Ekonomik Gelişmeleri Takip Etme ve Boyutlar Arasındaki ilişski}

Ekonomik gelişmeleri takip etme değişkeni dört alt gruptan oluşmakta olup, gruplar ile finansal okuryazarlık boyutları arasındaki anlamlılık sınamasına ait sonuçlar Tablo 9'da sunulmuştur. 
Tablo 9

Ekonomik Gelişmeleri Takip Etme Bakımından Boyutlar Arası Anlamlılık

\begin{tabular}{|c|c|c|c|c|c|}
\hline & Ekonomik Gelişme & $\mathbf{N}$ & Ortalama & Ki-Kare & $\mathbf{P}$ \\
\hline \multirow[t]{4}{*}{ Harcama } & Düzenli takip ederim & 130 & 130,57 & \multirow{4}{*}{6,781} & \multirow{4}{*}{$0,079^{* *}$} \\
\hline & Bazen takip ederim & 86 & 118,27 & & \\
\hline & Nadiren takip ettiğim olur & 20 & 132,10 & & \\
\hline & Hayır, takip etmiyorum & 11 & 76,45 & & \\
\hline \multirow[t]{4}{*}{ Tutum } & Düzenli takip ederim & 130 & 102,39 & \multirow{4}{*}{27,623} & \multirow{4}{*}{$0,001^{\star}$} \\
\hline & Bazen takip ederim & 86 & 143,16 & & \\
\hline & Nadiren takip ettiğim olur & 20 & 151,80 & & \\
\hline & Hayır, takip etmiyorum & 11 & 179,00 & & \\
\hline \multirow[t]{4}{*}{ İlgi } & Düzenli takip ederim & 130 & 95,87 & \multirow{4}{*}{43,763} & \multirow{4}{*}{$0,000^{*}$} \\
\hline & Bazen takip ederim & 86 & 151,17 & & \\
\hline & Nadiren takip ettiğim olur & 20 & 162,80 & & \\
\hline & Hayır, takip etmiyorum & 11 & 173,45 & & \\
\hline \multirow[t]{4}{*}{ Alg1 } & Düzenli takip ederim & 130 & 125,58 & \multirow{4}{*}{4,133} & \multirow{4}{*}{0,247} \\
\hline & Bazen takip ederim & 86 & 119,30 & & \\
\hline & Nadiren takip ettiğim olur & 20 & 112,75 & & \\
\hline & Hayır, takip etmiyorum & 11 & 162,55 & & \\
\hline
\end{tabular}

*\%5 önem düzeyinde anlamlı.

**\%10 önem düzeyinde anlaml.

Ekonomik gelişmeleri takip etme bakımından test edilecek hipotezler aşağıdaki gibidir:

He: Katılımcıların ekonomik gelişmeleri takip etmesi finansal okuryazarlık ölçeğine ait boyutlara bakış açılarını etkilememektedir.

$H_{1}$ : Katılımcıların ekonomik gelişmeleri takip etmesi finansal okuryazarlı ölçeğine ait boyutlara bakış açılarını etkilemektedir.

Ekonomik gelişmeleri takip etme bakımından oluşturulan gruplar ile finansal okuryazarlık boyutları arasında \%5 önem düzeyinde ve \%10 önem düzeyinde istatistiksel olarak anlamlı ilişkiler saptanmıştır. Tutum $(\mathrm{p}=0,001<0,05)$ ve ilgi $(\mathrm{p}=0,000<0,05)$ boyutları için hesaplanan $\mathrm{p}$ anlamlılık değerleri \%5 önem düzeyinden küçük olduğundan $\mathrm{H}_{0}$ hipotezi bu alt boyutlarda reddedilmiştir. \%10 önem düzeyinde ise harcama boyutunda $(\mathrm{p}=0,079<0,10)$ istatistiksel olarak anlamlı fark bulunmuştur. Ekonomik gelişmeleri düzenli takip eden, bazen takip eden, nadiren takip eden ve takip etmeyen katılımcıların harcama, tutum ve ilgi boyutlarında algılamalarının farklı olduğu sonucuna varılmıştır.

\section{Aile Ortalama Geliri ve Boyutlar Arasındaki ilişki}

Aile ortalama gelirine ait değerler beş grupta toplanmış olup, gruplar ile finansal okuryazarlık boyutları arasındaki anlamlılığı sınamaya ait sonuçlar Tablo 10 'da sunulmuştur. 
Tablo 10

Aile Ortalama Gelirine Göre Boyutlar Arası Anlamlılık

\begin{tabular}{|c|c|c|c|c|c|}
\hline & Aile Ortalama Geliri & $\mathbf{N}$ & Ortalama & Ki-Kare & $\mathbf{P}$ \\
\hline \multirow[t]{5}{*}{ Harcama } & $5.000-7.500$ & 84 & 119,67 & \multirow{5}{*}{0,946} & \multirow{5}{*}{0,918} \\
\hline & $7.501-10.000$ & 72 & 127,36 & & \\
\hline & $10.001-12.500$ & 44 & 123,76 & & \\
\hline & $12.501-15.000$ & 34 & 122,71 & & \\
\hline & $15.001+$ & 13 & 137,54 & & \\
\hline \multirow[t]{5}{*}{ Tutum } & $5.000-7.500$ & 84 & 113,28 & \multirow{5}{*}{5,808} & \multirow{5}{*}{0,214} \\
\hline & $7.501-10.000$ & 72 & 138,82 & & \\
\hline & $10.001-12.500$ & 44 & 117,31 & & \\
\hline & $12.501-15.000$ & 34 & 130,62 & & \\
\hline & $15.001+$ & 13 & 116,54 & & \\
\hline \multirow[t]{5}{*}{ İlgi } & $5.000-7.500$ & 84 & 137,35 & \multirow{5}{*}{7,458} & \multirow{5}{*}{0,114} \\
\hline & $7.501-10.000$ & 72 & 106,96 & & \\
\hline & $10.001-12.500$ & 44 & 125,69 & & \\
\hline & $12.501-15.000$ & 34 & 128,74 & & \\
\hline & $15.001+$ & 13 & 114,00 & & \\
\hline \multirow[t]{5}{*}{ Alg1 } & $5.000-7.500$ & 84 & 121,16 & \multirow{5}{*}{2,449} & \multirow{5}{*}{0,654} \\
\hline & 7.501-10.000 & 72 & 121,39 & & \\
\hline & $10.001-12.500$ & 44 & 126,38 & & \\
\hline & $12.501-15.000$ & 34 & 122,35 & & \\
\hline & $15.001+$ & 13 & 153,08 & & \\
\hline
\end{tabular}

Aile ortalama gelir bakımından test edilecek hipotezler aşağıdaki gibidir:

$H f_{o}$ : Katılımcılara ait aile ortalama gelirleri ile finansal okuryazarlık ölçeğine ait boyutlara bakış açıları arasinda fark yoktur.

Hf : Katılımcılara ait aile ortalama gelirleri ile finansal okuryazarlık ölçeğine ait boyutlara bakış açıları arasinda fark vardir.

Bireylerin aile ortalama gelirleri ile finansal okuryazarlık boyutları arasında anlamlı bir ilişki saptanamamıştır ( $p>0,05 ; p>0,10)$. Katılımcıların aile aylık ortalama gelirlerine göre harcama, tutum, ilgi ve algı boyutlarına bakış açıları arasında bir farklılığın olmadığı söylenebilmektedir.

\section{Yaş ve Boyutlar Arasındaki ilişski}

Yaş bakımından gruplar "20-30 arası", "31-40 arası", “41-50 arası", "51-60 arası” ve "61 yaş ve üzeri” şeklinde oluşturulmuştur. Oluşturulan yaş grupları ile finansal okuryazarlık boyutları arasındaki ilişkilere ait sonuçlar Tablo 11'de sunulmuştur. 
Tablo 11

Yaşa Göre Boyutlar Arası Anlamlılık

\begin{tabular}{|c|c|c|c|c|c|}
\hline & Yaş & $\mathbf{N}$ & Ortalama & Ki-Kare & $\mathbf{P}$ \\
\hline \multirow[t]{5}{*}{ Harcama } & $20-30$ & 38 & 117,74 & \multirow{5}{*}{3,628} & \multirow{5}{*}{0,459} \\
\hline & $31-40$ & 80 & 128,81 & & \\
\hline & $41-50$ & 93 & 121,66 & & \\
\hline & $51-60$ & 33 & 132,03 & & \\
\hline & 61 ve üzeri & 3 & 59,33 & & \\
\hline \multirow[t]{5}{*}{ Tutum } & $20-30$ & 38 & 122,18 & \multirow{5}{*}{5,580} & \multirow{5}{*}{0,233} \\
\hline & $31-40$ & 80 & 136,39 & & \\
\hline & $41-50$ & 93 & 111,54 & & \\
\hline & $51-60$ & 33 & 131,03 & & \\
\hline & 61 ve üzeri & 3 & 125,33 & & \\
\hline \multirow[t]{5}{*}{ İlgi } & $20-30$ & 38 & 118,13 & \multirow{5}{*}{3,622} & \multirow{5}{*}{0,460} \\
\hline & $31-40$ & 80 & 126,23 & & \\
\hline & $41-50$ & 93 & 117,70 & & \\
\hline & $51-60$ & 33 & 143,79 & & \\
\hline & 61 ve üzeri & 3 & 116,33 & & \\
\hline \multirow[t]{5}{*}{ Alg1 } & $20-30$ & 38 & 95,55 & \multirow{5}{*}{18,810} & \multirow{5}{*}{$0,001^{\star}$} \\
\hline & $31-40$ & 80 & 114,11 & & \\
\hline & $41-50$ & 93 & 130,06 & & \\
\hline & $51-60$ & 33 & 156,33 & & \\
\hline & 61 ve üzeri & 3 & 204,67 & & \\
\hline
\end{tabular}

*\%5 önem düzeyinde anlamlı.

Yaş bakımından oluşturulan gruplara ilişkin olarak test edilecek hipotezler aşağıdaki gibidir:

$H g_{0}:$ Katılımcıların yaşları finansal okuryazarlık ölçeğine ait boyutlara bakış açılarını etkilememektedir. $\mathrm{Hg}_{1}$ : Katılımcıların yaşları finansal okuryazarlık ölçeğine ait boyutlara bakış açılarını etkilemektedir.

Yaş değişkeninin finansal okuryazarlık boyutlarına bakışına etkisi araştırıldığında sadece algı boyutunda yaş grupları arasında \%5 önem düzeyinde anlamlı bir farklılık $(\mathrm{p}=0,001<0,05)$ olduğu saptanmıştır. Diğer boyutlar için katılımcıların yaşlarına göre bakış açılarında farklılık olmadığı tespit edilmiştir ( $p>0,05 ; p>0,10)$.

\section{Medeni Durum ve Boyutlar Arasındaki ilişki}

Medeni durum bakımından evli, hiç evlenmedi ve boşanmış olmak üzere oluşan gruplara yönelik yapılan finansal okuryazarlık ölçeğinin boyutlarına ait ilişkilerin anlamlılığı Tablo 12'de sunulmuştur. 
Tablo 12

Medeni Durumuna Göre Faktörler Arası Anlamlılık

\begin{tabular}{|c|c|c|c|c|c|}
\hline & Medeni Durum & $\mathbf{N}$ & Ortalama & $\begin{array}{c}\text { Ki- } \\
\text { Kare }\end{array}$ & $\mathbf{P}$ \\
\hline \multirow[t]{3}{*}{ Harcama } & Hiç Evlenmedi & 52 & 107,46 & \multirow{3}{*}{3,734} & \multirow{3}{*}{0,155} \\
\hline & Evli & 186 & 128,92 & & \\
\hline & Boşanmış & 9 & 117,89 & & \\
\hline \multirow[t]{3}{*}{ Tutum } & Hiç Evlenmedi & 52 & 123,92 & \multirow{3}{*}{0,118} & \multirow{3}{*}{0,943} \\
\hline & Evli & 186 & 123,63 & & \\
\hline & Boşanmış & 9 & 132,00 & & \\
\hline \multirow[t]{3}{*}{ İlgi } & Hiç Evlenmedi & 52 & 134,96 & \multirow{3}{*}{1,775} & \multirow{3}{*}{0,412} \\
\hline & Evli & 186 & 120,54 & & \\
\hline & Boşanmış & 9 & 132,11 & & \\
\hline \multirow[t]{3}{*}{ Alg1 } & Hiç Evlenmedi & 52 & 109,65 & \multirow{3}{*}{2,976} & \multirow{3}{*}{0,226} \\
\hline & Evli & 186 & 128,46 & & \\
\hline & Boşanmış & 9 & 114,67 & & \\
\hline
\end{tabular}

Medeni durum bakımından test edilecek hipotezler aşağıdaki gibidir:

$H_{0}:$ Katılımcıların medeni durumları boyutlara bakış açılarını etkilememektedir.

$H_{1}$ : Katılımcıların medeni durumları boyutlara bakış açılarını etkilemektedir.

Katılımcıların medeni durumlarının faktörleri algılamada farklılık yaratıp yaratmadığının sınanması sonucunda değişkenler arasında anlamlı bir farklılık bulunamamıştır. $\mathrm{H}_{\mathrm{o}}$ hipotezi tüm boyutlar için gerek \%5 gerekse \%10 önem düzeyinde reddedilememiştir ( $>0,05 ; p>0,10)$. Bilim adamlarının, finansal okuryazarlık ölçeğine ait boyutlara bakış açılarının medeni duruma göre farklılık göstermediği, algılamalarının benzer özellik gösterdiği saptanmıştır.

\section{Finansal Kavramların Bilinirliği ve Boyutlar Arasındaki iliş̧ki}

Finansal kavramların bilinirliği ile finansal okuryazarlık boyutları arasındaki anlamlılık araştırıldığında elde edilen sonuçlar Tablo 13’te gösterilmiştir. 
Tablo 13

Finansal Kavramların Bilinirliği Yönüyle Boyutlar Arası Anlamlılık

\begin{tabular}{|c|c|c|c|c|c|c|}
\hline & & & $\mathbf{N}$ & Ort. & Ki-kare & $\mathbf{P}$ \\
\hline \multirow{12}{*}{ Enflasyon } & Harcama & Tam Anlamıyla Tanımlayabilirim & 194 & 125,19 & \multirow{3}{*}{7,116} & \multirow{3}{*}{$0,028^{\star}$} \\
\hline & & $\begin{array}{l}\text { Ne olduğu hakkında fikrim var ancak } \\
\text { tanımlayamam }\end{array}$ & 50 & 125,93 & & \\
\hline & & Fikrim yok & 3 & 14,67 & & \\
\hline & \multirow[t]{3}{*}{ Tutum } & Tam Anlamıyla Tanımlayabilirim & 194 & 122,06 & \multirow{3}{*}{1,615} & \multirow{3}{*}{0,446} \\
\hline & & $\begin{array}{l}\text { Ne olduğu hakkında fikrim var ancak } \\
\text { tanımlayamam }\end{array}$ & 50 & 133,43 & & \\
\hline & & Fikrim yok & 3 & 92,00 & & \\
\hline & \multirow[t]{3}{*}{ İlgi } & Tam Anlamıyla Tanımlayabilirim & 194 & 117,16 & \multirow{3}{*}{8,422} & \multirow{3}{*}{$0,015^{\star}$} \\
\hline & & $\begin{array}{l}\text { Ne olduğu hakkında fikrim var ancak } \\
\text { tanımlayamam }\end{array}$ & 50 & 149,91 & & \\
\hline & & Fikrim yok & 3 & 134,67 & & \\
\hline & \multirow[t]{3}{*}{ Alg1 } & Tam Anlamıyla Tanımlayabilirim & 194 & 123,11 & \multirow{3}{*}{0,743} & \multirow{3}{*}{0,690} \\
\hline & & $\begin{array}{l}\text { Ne olduğu hakkında fikrim var ancak } \\
\text { tanımlayamam }\end{array}$ & 50 & 125,11 & & \\
\hline & & Fikrim yok & 3 & 158,33 & & \\
\hline \multirow{12}{*}{ Faiz } & \multirow[t]{3}{*}{ Harcama } & Tam Anlamıyla Tanımlayabilirim & 214 & 123,11 & \multirow{3}{*}{2,595} & \multirow{3}{*}{0,273} \\
\hline & & $\begin{array}{l}\text { Ne olduğu hakkında fikrim var ancak } \\
\text { tanımlayamam }\end{array}$ & 32 & 133,14 & & \\
\hline & & Fikrim yok & 1 & 22,00 & & \\
\hline & \multirow[t]{3}{*}{ Tutum } & Tam Anlamıyla Tanımlayabilirim & 214 & 122,14 & \multirow{3}{*}{2,794} & \multirow{3}{*}{0,247} \\
\hline & & $\begin{array}{l}\text { Ne olduğu hakkında fikrim var ancak } \\
\text { tanımlayamam }\end{array}$ & 32 & 138,92 & & \\
\hline & & Fikrim yok & 1 & 44,00 & & \\
\hline & \multirow[t]{3}{*}{ İlgi } & Tam Anlamıyla Tanımlayabilirim & 214 & 121,41 & \multirow{3}{*}{2,705} & \multirow{3}{*}{0,259} \\
\hline & & $\begin{array}{l}\text { Ne olduğu hakkında fikrim var ancak } \\
\text { tanımlayamam }\end{array}$ & 32 & 142,48 & & \\
\hline & & Fikrim yok & 1 & 86,00 & & \\
\hline & \multirow[t]{3}{*}{ Alg1 } & Tam Anlamıyla Tanımlayabilirim & 214 & 123,13 & \multirow{3}{*}{0,556} & \multirow{3}{*}{0,757} \\
\hline & & $\begin{array}{l}\text { Ne olduğu hakkında fikrim var ancak } \\
\text { tanımlayamam }\end{array}$ & 32 & 130,89 & & \\
\hline & & Fikrim yok & 1 & 90,00 & & \\
\hline \multirow{12}{*}{ İşsizlik } & Harcama & Tam Anlamıyla Tanımlayabilirim & 226 & 123,42 & \multirow{3}{*}{1,855} & \\
\hline & & $\begin{array}{l}\text { Ne olduğu hakkında fikrim var ancak } \\
\text { tanımlayamam }\end{array}$ & 19 & 136,82 & & 0,396 \\
\hline & & Fikrim yok & 2 & 68,00 & & \\
\hline & Tutum & Tam Anlamıyla Tanımlayabilirim & 226 & 125,29 & & \\
\hline & & $\begin{array}{l}\text { Ne olduğu hakkında fikrim var ancak } \\
\text { tanımlayamam }\end{array}$ & 19 & 113,29 & 1,259 & 0,533 \\
\hline & & Fikrim yok & 2 & 80,00 & & \\
\hline & İlgi & Tam Anlamıyla Tanımlayabilirim & 226 & 123,42 & & \\
\hline & & $\begin{array}{l}\text { Ne olduğu hakkında fikrim var ancak } \\
\text { tanımlayamam }\end{array}$ & 19 & 128,66 & 0,277 & 0,871 \\
\hline & & Fikrim yok & 2 & 145,50 & & \\
\hline & Alg1 & Tam Anlamıyla Tanımlayabilirim & 226 & 121,81 & & \\
\hline & & $\begin{array}{l}\text { Ne olduğu hakkında fikrim var ancak } \\
\text { tanımlayamam }\end{array}$ & 19 & 148,03 & 2,502 & 0,286 \\
\hline & & Fikrim yok & 2 & 143,00 & & \\
\hline
\end{tabular}


Tablo 13 (Devamı)

Finansal Kavramların Bilinirliği Yönüyle Boyutlar Arası Anlamlılık

\begin{tabular}{|c|c|c|c|c|c|c|}
\hline & & & $\mathbf{N}$ & Ort. & Ki-kare & $\mathbf{P}$ \\
\hline \multirow{12}{*}{ Tasarruf } & \multirow[t]{3}{*}{ Harcama } & Tam Anlamıyla Tanımlayabilirim & 200 & 129,44 & \multirow{3}{*}{6,450} & \multirow{3}{*}{$0,040^{*}$} \\
\hline & & $\begin{array}{l}\text { Ne olduğu hakkında fikrim var ancak } \\
\text { tanımlayamam }\end{array}$ & 43 & 98,95 & & \\
\hline & & Fikrim yok & 4 & 121,25 & & \\
\hline & \multirow[t]{3}{*}{ Tutum } & Tam Anlamıyla Tanımlayabilirim & 200 & 122,77 & \multirow{3}{*}{0,904} & \multirow{3}{*}{0,636} \\
\hline & & $\begin{array}{l}\text { Ne olduğu hakkında fikrim var ancak } \\
\text { tanımlayamam }\end{array}$ & 43 & 126,81 & & \\
\hline & & Fikrim yok & 4 & 155,50 & & \\
\hline & \multirow[t]{3}{*}{ İlgi } & Tam Anlamıyla Tanımlayabilirim & 200 & 120,69 & \multirow{3}{*}{3,667} & \multirow{3}{*}{0,160} \\
\hline & & $\begin{array}{l}\text { Ne olduğu hakkında fikrim var ancak } \\
\text { tanımlayamam }\end{array}$ & 43 & 141,86 & & \\
\hline & & Fikrim yok & 4 & 97,50 & & \\
\hline & \multirow[t]{3}{*}{ Alg1 } & Tam Anlamıla Tanımlayabilirim & 200 & 119,47 & \multirow{3}{*}{5,852} & \multirow{3}{*}{$0,054^{\star *}$} \\
\hline & & $\begin{array}{l}\text { Ne olduğu hakkında fikrim var ancak } \\
\text { tanımlayamam }\end{array}$ & 43 & 139,26 & & \\
\hline & & Fikrim yok & 4 & 186,75 & & \\
\hline \multirow{12}{*}{$\begin{array}{l}\text { Hisse } \\
\text { Senedi }\end{array}$} & \multirow[t]{3}{*}{ Harcama } & Tam Anlamıyla Tanımlayabilirim & 122 & 130,18 & \multirow{3}{*}{2,506} & \multirow{3}{*}{0,286} \\
\hline & & $\begin{array}{l}\text { Ne olduğu hakkında fikrim var ancak } \\
\text { tanımlayamam }\end{array}$ & 98 & 120,77 & & \\
\hline & & Fikrim yok & 27 & 107,78 & & \\
\hline & \multirow[t]{3}{*}{ Tutum } & Tam Anlamıyla Tanımlayabilirim & 122 & 121,81 & \multirow{3}{*}{2,230} & \multirow{3}{*}{0,328} \\
\hline & & $\begin{array}{l}\text { Ne olduğu hakkında fikrim var ancak } \\
\text { tanımlayamam }\end{array}$ & 98 & 121,39 & & \\
\hline & & Fikrim yok & 27 & 143,37 & & \\
\hline & \multirow[t]{3}{*}{ İlgi } & Tam Anlamıyla Tanımlayabilirim & 122 & 113,86 & \multirow{3}{*}{5,091} & \multirow{3}{*}{$0,078^{\star *}$} \\
\hline & & $\begin{array}{l}\text { Ne olduğu hakkında fikrim var ancak } \\
\text { tanımlayamam }\end{array}$ & 98 & 132,25 & & \\
\hline & & Fikrim yok & 27 & 139,85 & & \\
\hline & \multirow[t]{3}{*}{ Alg1 } & Tam Anlamıyla Tanımlayabilirim & 122 & 120,96 & \multirow{3}{*}{1,395} & \multirow{3}{*}{0,498} \\
\hline & & $\begin{array}{l}\text { Ne olduğu hakkında fikrim var ancak } \\
\text { tanımlayamam }\end{array}$ & 98 & 123,68 & & \\
\hline & & Fikrim yok & 27 & 138,89 & & \\
\hline \multirow{12}{*}{$\begin{array}{l}\text { Yatırım } \\
\text { Fonu }\end{array}$} & Harcama & Tam Anlamıyla Tanımlayabilirim & 96 & 129,03 & & \\
\hline & & $\begin{array}{l}\text { Ne olduğu hakkında fikrim var ancak } \\
\text { tanımlayamam }\end{array}$ & 115 & 124,60 & 2,135 & 0,344 \\
\hline & & Fikrim yok & 36 & 108,69 & & \\
\hline & Tutum & Tam Anlamıyla Tanımlayabilirim & 96 & 113,32 & & \\
\hline & & $\begin{array}{l}\text { Ne olduğu hakkında fikrim var ancak } \\
\text { tanımlayamam }\end{array}$ & 115 & 125,92 & 5,755 & $0,056^{* *}$ \\
\hline & & Fikrim yok & 36 & 146,36 & & \\
\hline & İlgi & Tam Anlamıyla Tanımlayabilirim & 96 & 115,27 & & \\
\hline & & $\begin{array}{l}\text { Ne olduğu hakkında fikrim var ancak } \\
\text { tanımlayamam }\end{array}$ & 115 & 127,83 & 2,627 & 0,269 \\
\hline & & Fikrim yok & 36 & 135,06 & & \\
\hline & Alg1 & Tam Anlamıyla Tanımlayabilirim & 96 & 124,86 & & \\
\hline & & $\begin{array}{l}\text { Ne olduğu hakkında fikrim var ancak } \\
\text { tanımlayamam }\end{array}$ & 115 & 113,60 & 9,206 & $0,10^{* *}$ \\
\hline & & Fikrim yok & 36 & 154,94 & & \\
\hline
\end{tabular}


Tablo 13 (Devamı)

Finansal Kavramların Bilinirliği Yönüyle Boyutlar Arası Anlamlılık

\begin{tabular}{|c|c|c|c|c|c|c|}
\hline & & & $\mathbf{N}$ & Ort. & Ki-kare & $\mathbf{P}$ \\
\hline \multirow{12}{*}{ Döviz } & \multirow[t]{3}{*}{ Harcama } & Tam Anlamıyla Tanımlayabilirim & 220 & 125,08 & \multirow{3}{*}{1,402} & \multirow{3}{*}{0,496} \\
\hline & & $\begin{array}{l}\text { Ne olduğu hakkında fikrim var ancak } \\
\text { tanımlayamam }\end{array}$ & 25 & 118,98 & & \\
\hline & & Fikrim yok & 2 & 68,00 & & \\
\hline & \multirow[t]{3}{*}{ Tutum } & Tam Anlamıyla Tanımlayabilirim & 220 & 123,20 & \multirow{3}{*}{1,334} & \multirow{3}{*}{0,513} \\
\hline & & $\begin{array}{l}\text { Ne olduğu hakkında fikrim var ancak } \\
\text { tanımlayamam }\end{array}$ & 25 & 134,58 & & \\
\hline & & Fikrim yok & 2 & 80,00 & & \\
\hline & \multirow[t]{3}{*}{ İlgi } & Tam Anlamıyla Tanımlayabilirim & 220 & 122,33 & \multirow{3}{*}{1,132} & \multirow{3}{*}{0,568} \\
\hline & & $\begin{array}{l}\text { Ne olduğu hakkında fikrim var ancak } \\
\text { tanımlayamam }\end{array}$ & 25 & 137,02 & & \\
\hline & & Fikrim yok & 2 & 145,50 & & \\
\hline & \multirow[t]{3}{*}{ Alg1 } & Tam Anlamıla Tanımlayabilirim & 220 & 124,79 & \multirow{3}{*}{0,522} & \multirow{3}{*}{0,770} \\
\hline & & $\begin{array}{l}\text { Ne olduğu hakkında fikrim var ancak } \\
\text { tanımlayamam }\end{array}$ & 25 & 115,50 & & \\
\hline & & Fikrim yok & 2 & 143,00 & & \\
\hline \multirow{12}{*}{ Senet } & \multirow[t]{3}{*}{ Harcama } & Tam Anlamıyla Tanımlayabilirim & 169 & 126,09 & \multirow{3}{*}{0,706} & \multirow{3}{*}{0,703} \\
\hline & & $\begin{array}{l}\text { Ne olduğu hakkında fikrim var ancak } \\
\text { tanımlayamam }\end{array}$ & 69 & 120,92 & & \\
\hline & & Fikrim yok & 9 & 108,33 & & \\
\hline & \multirow[t]{3}{*}{ Tutum } & Tam Anlamıyla Tanımlayabilirim & 169 & 118,22 & \multirow{3}{*}{3,806} & \multirow{3}{*}{0,149} \\
\hline & & $\begin{array}{l}\text { Ne olduğu hakkında fikrim var ancak } \\
\text { tanımlayamam }\end{array}$ & 69 & 134,93 & & \\
\hline & & Fikrim yok & 9 & 148,78 & & \\
\hline & \multirow[t]{3}{*}{ İlgi } & Tam Anlamıyla Tanımlayabilirim & 169 & 120,43 & \multirow{3}{*}{3,788} & \multirow{3}{*}{0,150} \\
\hline & & $\begin{array}{l}\text { Ne olduğu hakkında fikrim var ancak } \\
\text { tanımlayamam }\end{array}$ & 69 & 136,31 & & \\
\hline & & Fikrim yok & 9 & 96,67 & & \\
\hline & \multirow[t]{3}{*}{ Alg1 } & Tam Anlamıyla Tanımlayabilirim & 169 & 121,02 & \multirow{3}{*}{3,309} & \multirow{3}{*}{0,191} \\
\hline & & $\begin{array}{l}\text { Ne olduğu hakkında fikrim var ancak } \\
\text { tanımlayamam }\end{array}$ & 69 & 125,95 & & \\
\hline & & Fikrim yok & 9 & 165,00 & & \\
\hline \multirow{12}{*}{ Çek } & Harcama & Tam Anlamıyla Tanımlayabilirim & 169 & 127,13 & & \\
\hline & & $\begin{array}{l}\text { Ne olduğu hakkında fikrim var ancak } \\
\text { tanımlayamam }\end{array}$ & 64 & 115,54 & 1,225 & 0,542 \\
\hline & & Fikrim yok & 14 & 124,86 & & \\
\hline & Tutum & Tam Anlamıyla Tanımlayabilirim & 169 & 116,34 & & \\
\hline & & $\begin{array}{l}\text { Ne olduğu hakkında fikrim var ancak } \\
\text { tanımlayamam }\end{array}$ & 64 & 136,80 & 7,155 & $0,028^{\star}$ \\
\hline & & Fikrim yok & 14 & 157,93 & & \\
\hline & İlgi & Tam Anlamıyla Tanımlayabilirim & 169 & 120,16 & & \\
\hline & & $\begin{array}{l}\text { Ne olduğu hakkında fikrim var ancak } \\
\text { tanımlayamam }\end{array}$ & 64 & 136,57 & 2,806 & 0,246 \\
\hline & & Fikrim yok & 14 & 112,93 & & \\
\hline & Alg1 & Tam Anlamıyla Tanımlayabilirim & 169 & 120,78 & & \\
\hline & & $\begin{array}{l}\text { Ne olduğu hakkında fikrim var ancak } \\
\text { tanımlayamam }\end{array}$ & 64 & 123,95 & 4,529 & 0,104 \\
\hline & & Fikrim yok & 14 & 163,07 & & \\
\hline
\end{tabular}


Tablo 13 (Devam)

Finansal Kavramların Bilinirliği Yönüyle Boyutlar Arası Anlamlılık

\begin{tabular}{|c|c|c|c|c|c|c|}
\hline & & & $\mathbf{N}$ & Ort. & Ki-kare & $\mathbf{P}$ \\
\hline \multirow{12}{*}{$\begin{array}{l}\text { Bireysel } \\
\text { Emeklilik }\end{array}$} & \multirow[t]{3}{*}{ Harcama } & Tam Anlamıyla Tanımlayabilirim & 178 & 124,95 & \multirow{3}{*}{1,634} & \multirow{3}{*}{0,442} \\
\hline & & $\begin{array}{l}\text { Ne olduğu hakkında fikrim var ancak } \\
\text { tanımlayamam }\end{array}$ & 61 & 125,39 & & \\
\hline & & Fikrim yok & 8 & 92,25 & & \\
\hline & \multirow[t]{3}{*}{ Tutum } & Tam Anlamıyla Tanımlayabilirim & 178 & 116,83 & \multirow{3}{*}{6,570} & \multirow{3}{*}{$0,037^{\star}$} \\
\hline & & $\begin{array}{l}\text { Ne olduğu hakkında fikrim var ancak } \\
\text { tanımlayamam }\end{array}$ & 61 & 143,72 & & \\
\hline & & Fikrim yok & 8 & 133,13 & & \\
\hline & \multirow[t]{3}{*}{ İlgi } & Tam Anlamıyla Tanımlayabilirim & 178 & 122,21 & \multirow{3}{*}{0,538} & \multirow{3}{*}{0,764} \\
\hline & & $\begin{array}{l}\text { Ne olduğu hakkında fikrim var ancak } \\
\text { tanımlayamam }\end{array}$ & 61 & 129,77 & & \\
\hline & & Fikrim yok & 8 & 119,75 & & \\
\hline & \multirow[t]{3}{*}{ Alg1 } & Tam Anlamıyla Tanımlayabilirim & 178 & 117,06 & \multirow{3}{*}{6,072} & \multirow{3}{*}{$0,048^{\star}$} \\
\hline & & $\begin{array}{l}\text { Ne olduğu hakkında fikrim var ancak } \\
\text { tanımlayamam }\end{array}$ & 61 & 141,11 & & \\
\hline & & Fikrim yok & 8 & 147,88 & & \\
\hline \multirow{12}{*}{ Yatırım } & \multirow[t]{3}{*}{ Harcama } & Tam Anlamıyla Tanımlayabilirim & 187 & 129,09 & \multirow{3}{*}{3,925} & \multirow{3}{*}{0,141} \\
\hline & & $\begin{array}{l}\text { Ne olduğu hakkında fikrim var ancak } \\
\text { tanımlayamam }\end{array}$ & 54 & 107,74 & & \\
\hline & & Fikrim yok & 6 & 111,67 & & \\
\hline & \multirow[t]{3}{*}{ Tutum } & Tam Anlamıyla Tanımlayabilirim & 187 & 117,33 & \multirow{3}{*}{6,773} & \multirow{3}{*}{$0,034^{*}$} \\
\hline & & $\begin{array}{l}\text { Ne olduğu hakkında fikrim var ancak } \\
\text { tanımlayamam }\end{array}$ & 54 & 144,07 & & \\
\hline & & Fikrim yok & 6 & 151,33 & & \\
\hline & \multirow[t]{3}{*}{ İlgi } & Tam Anlamıyla Tanımlayabilirim & 187 & 121,20 & \multirow{3}{*}{1,198} & \multirow{3}{*}{0,549} \\
\hline & & $\begin{array}{l}\text { Ne olduğu hakkında fikrim var ancak } \\
\text { tanımlayamam }\end{array}$ & 54 & 133,13 & & \\
\hline & & Fikrim yok & 6 & 129,00 & & \\
\hline & \multirow[t]{3}{*}{ Alg1 } & Tam Anlamıyla Tanımlayabilirim & 187 & 119,49 & \multirow{3}{*}{3,158} & \multirow{3}{*}{0,206} \\
\hline & & $\begin{array}{l}\text { Ne olduğu hakkında fikrim var ancak } \\
\text { tanımlayamam }\end{array}$ & 54 & 137,17 & & \\
\hline & & Fikrim yok & 6 & 146,17 & & \\
\hline \multirow{12}{*}{$\begin{array}{l}\text { Katılım } \\
\text { Bankası }\end{array}$} & Harcama & Tam Anlamıyla Tanımlayabilirim & 94 & 137,71 & & \\
\hline & & $\begin{array}{l}\text { Ne olduğu hakkında fikrim var ancak } \\
\text { tanımlayamam }\end{array}$ & 111 & 123,75 & 10,881 & $0,004^{*}$ \\
\hline & & Fikrim yok & 42 & 93,98 & & \\
\hline & Tutum & Tam Anlamıyla Tanımlayabilirim & 94 & 119,79 & & \\
\hline & & $\begin{array}{l}\text { Ne olduğu hakkında fikrim var ancak } \\
\text { tanımlayamam }\end{array}$ & 111 & 120,32 & 3,645 & 0,162 \\
\hline & & Fikrim yok & 42 & 143,17 & & \\
\hline & İlgi & Tam Anlamıyla Tanımlayabilirim & 94 & 109,37 & & \\
\hline & & $\begin{array}{l}\text { Ne olduğu hakkında fikrim var ancak } \\
\text { tanımlayamam }\end{array}$ & 111 & 131,15 & 6,627 & $0,036^{*}$ \\
\hline & & Fikrim yok & 42 & 137,83 & & \\
\hline & Alg1 & Tam Anlamıyla Tanımlayabilirim & 94 & 123,11 & & \\
\hline & & $\begin{array}{l}\text { Ne olduğu hakkında fikrim var ancak } \\
\text { tanımlayamam }\end{array}$ & 111 & 120,29 & 1,462 & 0,481 \\
\hline & & Fikrim yok & 42 & 135,81 & & \\
\hline
\end{tabular}

*\%5 önem düzeyinde anlaml.

* \% 10 önem düzeyinde anlamlı. 
Tablo 13 incelendiğinde çalışmaya katılan bilim insanlarının finansal kavramları tanımlayabilme, tanımlayamama ve kavram hakkında fikri olmaması durumunun finansal okuryazarlık boyutlarıyla ilişkisi araştırıldığında elde edilen sonuçlar iki başlık altında toplanarak aşağıda sunulmuştur.

Anlamlı fark bulunan kavramlar;

- Enflasyon kavramını tam olarak tanımlayabilen, ne olduğu hakkında fikri olan fakat tanımlayamayan ve de kavram hakkında fikri olmayan katılımcıların finansal okuryazarlık boyutlarına bakış açısı incelendiğinde harcama ve ilgi boyutlarında gruplar arasında \%5 önem düzeyinde anlamlı bir farklılık saptanmıştır.

- Tasarruf kavramı incelendiğinde tam olarak bilen, fikri olan fakat tanımlayamayan ve fikri olmayan gruplarda yer alan katılımcıların harcama boyutunda bakış açılarında \%5 önem düzeyinde ve algı boyutunda bakış açıları arasında \%10 önem düzeyinde anlamlı bir farklılık belirlenmiştir.

- Hisse senedi kavramı hakkındaki bilgileri \%10 önem düzeyinde ilgi boyutunda anlamlı bir farklılık göstermiştir.

- Yatırım fonu finansal kavramının gruplarca bilinme düzeyi \%10 önem düzeyinde tutum boyutunda ve $\% 5$ önem düzeyinde algı boyutunda farklılık saptanmasına sebep olmuştur.

- Çek kavramının anlamının bilinmesi düzeyinde boyutlar incelendiğinde gruplarda yer alan katılımcıların bakış açıları tutum boyutunda farklılık göstermektedir. Bu farklılık \%5 önem düzeyinde anlamlı bir sonuç vermektedir.

- Bireysel emeklilik ve boyutlar arasında ilişki incelendiğinde \%5 önem düzeyinde tutum ve algı boyutunda anlamlı farklılık olduğu görülmüştür

- Yatırım kavramı ve boyutlar arasındaki ilişki incelendiğinde, bu ilişkinin \%5 önem düzeyinde tutum boyutunda anlamlı olduğu yani grupların bu boyuta bakış açılarında anlamlı bir farklılığın olduğu saptanmıştır.

- Katılım bankası ve boyutlar arasındaki ilişki incelendiğinde, araştırılan ilişkinin \%5 önem düzeyinde harcama ve ilgi boyutlarında anlamlı olduğu belirlenmiştir.

Anlamlı fark bulunmayan kavramlar;

Bilim insanlarının finansal kavramlardan döviz, faiz, işsizlik ve senet kavramlarını tanımlayabilmesinin, tanımlayamamasının veya kavram hakkında fikri olmamasının her bir finansal okuryazarlık boyutunda anlamlı bir etkisinin olmadığı saptanmıştır.

\section{Sonuç}

Literatürde, finansal okuryazarlık üzerine yapılan çalışmalar her geçen gün artmaktadır. Ancak bu çalışmalar çoğunlukla, finansal okuryazarlık düzeyini belirlemeye yöneliktir. Bilim insanlarının finansal okuryazarlık tutum ve davranışlarını doğrudan inceleyen bir çalışmaya rastlanılamamıştır. Çalışmanın bu yönüyle literatüre katkı sağlaması arzulanmaktadır. Nitekim çalışmada, Niğde Ömer Halisdemir Üniversitesi’nde görev yapan bilim insanları arasında finansal okuryazarlık tutum ve davranış ölçeğinin harcama, algı, ilgi ve tutum bileşenleri açısından farklılık olup olmadığı ve finansal kavramlara dair bilgi düzeyleri ile finansal okuryazarlık tutum ve davranış ölçeğinin bileşenleri arasında ilişki olup olmadığı araştırılmıştır. Araştırma sonucunda istatistiksel olarak anlamlı sonuçlar elde edilmiştir. Buna göre:

- Niğde Ömer Halisdemir Üniversitesi’nde görev yapan bilim insanlarının; enflasyon, faiz, işsizlik, döviz, senet, çek, yatırım, tasarruf ve bireysel emeklilik kavramlarını hisse senedi, yatırım fonu ve katılım bankası kavramlarına kıyasla daha iyi bildikleri sonucuna ulaşılmıştır. Hisse senedi, yatırım 
fonu ve katılım bankası kavramlarının bilinme yüzdelerinin de \%40 dolayında olması örneklemdeki bilim insanlarının finansal kavramlara yönelik bilgi düzeylerinin düşük olmadığını göstermektedir.

- Niğde Ömer Halisdemir Üniversitesi’nde görev yapan bilim insanlarının finansal okuryazarlık tutum ve davranış ölçeğinin alt bileşenleri olan harcama, tutum, ilgi, algı boyutları ile demografik değişkenler arasındaki ilişkiler bağlamında; cinsiyet açısından ilgi ve algı boyutlarında anlamlı farklılık olduğu tespit edilmiştir. Ortalama sıra değerlerine bakıldığında kadınların ilgilerinin erkeklere göre daha yüksek, erkeklerin ise algılarının kadınlara oranla daha yüksek olduğu sonucuna ulaşılmıştır.

- Niğde Ömer Halisdemir Üniversitesi'nde görev yapan bilim insanlarının unvan açısından finansal okuryazarlık tutum ve davranış ölçeğinin alt bileşenleri olan harcama, tutum, ilgi, algı boyutları ile ilişkisi incelendiğinde \%10 önem düzeyinde harcama ve \%5 önem düzeyinde tutum boyutlarında anlamlı farklılık olduğu tespit edilmiştir. Ortalama sıra değerlerine bakıldığında Prof. Dr. unvanına sahip bilim insanlarının harcama konusunda daha istekli olduğu, Öğr. Gör. Dr. unvanına sahip bilim insanının ise harcama konusunda daha az istekli olduğu tespit edilmiştir. Ortalama sıra değerlerine bakıldığında Prof. Dr. unvanına sahip bilim insanlarının tutum açısından daha olumlu cevaplar verdiği tespit edilmiştir.

- Niğde Ömer Halisdemir Üniversitesi’nde görev yapan bilim insanlarının ekonomik gelişmeleri takip etme düzeyleri yönünden Gutnu ve Cihangir (2015) tarafından üniversite personeli üzerine yapılan çalışma ile benzer sonuçlara ulaşılmıştır. Bilim insanlarının ekonomik gelişmeleri takip etme açısından finansal okuryazarlık tutum ve davranış ölçeğinin alt bileşenleri olan harcama, tutum, ilgi, alg1 boyutları ile ilişkisi incelendiğinde \%5 önem düzeyinde tutum ve ilgi boyutlarında; \%10 önem düzeyinde harcama boyutunda anlamlı farklılık olduğu tespit edilmiştir. Harcama boyutu ortalama sıra değerlerine bakıldığında ekonomik gelişmeleri nadiren takip eden bilim insanlarının ekonomik gelişmeleri takip etmeyenlere göre daha fazla harcama eğiliminde olduğu; tutum ve ilgi boyutlarında ise ekonomik gelişmeleri takip etmeyenlerin daha olumlu yanıtlar verdiği tespit edilmiştir.

- Niğde Ömer Halisdemir Üniversitesi'nde görev yapan bilim insanlarının yaş açısından finansal okuryazarlık tutum ve davranış ölçeğinin alt bileşenleri olan harcama, tutum, ilgi, algı boyutları ile ilişkisi incelendiğinde \%5 önem düzeyinde algı boyutunda anlamlı bir farklılığın olduğu tespit edilmiştir. Ortalama sıra değerlerine bakıldığında 61 yaş üzeri katılımcıların 20-30 yaş aralığındaki katılımcılardan daha yüksek algıya sahip olduğu tespit edilmiştir.

- Buna karşın Niğde Ömer Halisdemir Üniversitesi'nde görev yapan bilim insanlarının eğitim düzeyi, medeni durumu, aile ortalama geliri ve çalışılan bilim alanı ile finansal okuryazarlık tutum ve davranış bileşenleri (harcama, tutum, ilgi ve algı) arasında anlamlı ilişkiler söz konusu değildir.

- Finansal okuryazarlık tutum ve davranış ölçeğinin alt bileşenleri olan harcama, tutum, ilgi, alg1 boyutları ile finansal kavramların bilinirliği bağlamında; tasarruf, yatırım, bireysel emeklilik kavramları hakkında fikri olmayan bilim insanlarının daha yüksek algıya sahip oldukları; yatırım ve çek kavramları hakkında fikri olmayan bilim insanlarının daha olumlu tutuma sahip olduğu, tasarruf ve katılım bankacılığı kavramlarını tam anlamıyla tanımlayabilen bilim insanlarının harcama eğilimlerinin daha yüksek olduğu, hisse senedi ve katılım bankacıllğı kavramları hakkında fikri olmayan bilim insanlarının ilgilerinin daha yüksek olduğu, enflasyon kavramı hakkında fikri olup ancak tanımlayamayan bilim insanlarının harcama eğilimlerinin ve ilgilerinin daha yüksek olduğu, yatırım kavramı hakkında fikri olmayan bilim insanlarının tutumlarının daha olumlu olduğu, bireysel emeklilik kavramı hakkında bilgi sahibi olup tanımlayamayan bilim insanlarının daha olumlu tutuma sahip olduğu tespit edilmiştir. Buna karşın döviz, faiz, işsizlik ve senet kavramların bilinirliği ile finansal okuryazarlık tutum ve davranış ölçeğinin bileşenleri (harcama, tutum, ilgi, algı) arasında anlamlı bir ilişki tespit edilememiştir. 
Durmuşkaya ve Kavas (2018) tarafından yapılan çalışmada akademik personelin cinsiyet, çalışılan bilim alanı, eğitim durumu, unvan ve yaş faktörlerine bağlı olarak finansal okuryazarlık düzeylerinin değiştiği tespit edilmesine karşın, bu çalışmada cinsiyet, unvan ve yaş finansal okuryazarlık tutum ve davranışlarında farklılığa sebep olurken; çalışılan bilim alanı ve eğitim durumu faktörlerinin finansal okuryazarlık tutum ve davranışında bir farlılığa sebep olmadığı tespit edilmiştir.

Araştırmanın eğitim-öğretim döneminin sona erdiği yaz döneminde gerçekleştirilmesi araştırmanın kısıtını oluşturmaktadır. Farklı disiplinlerde çalışan bilim insanlarının uzmanlık alanlarına göre finansal okuryazarlık tutum ve davranışlarına yönelik araştırma yapılması önerilebilir.

\section{Kaynakça}

Aksoylu, S., Boztosun, D., Altınışık, F. ve Baraz, E.H. (2017). A baseline investigation of financial literacy levels: The case of Kayseri province. Muhasebe ve Finansman Dergisi, 75, 229-246. doi:10.25095/mufad.399911

Altun, A. (2005). Gelişen teknolojiler ve yeni okuryazarlıklar. Ankara: Anı Yayınları.

Aşıcı, M. (2009). Kişisel ve sosyal bir değer olarak okuryazarlık. Değerler Eğitimi Dergisi, 7(17), 9-26. Erişim adresi: https://dergipark.org.tr/tr/pub/ded/issue/29183/312492

Atan, F., Biçer, E. B. (2017). Sağlık Bakanlığı'na bağlı hastanelerde çalışan sağlık personelinin finansal okuryazarlık düzeyinin belirlenmesi: Sivas ili örneği. Business \& Management Studies: An International Journal, 5(2), 481-499. Erişim adresi: https://app.trdizin.gov.tr/makale/TWpRd09URXINZz09/saglikbakanligina-bagli-hastanelerde-calisan-saglik-personelinin-finansal-okuryazarlik-duzeyininbelirlenmesi-sivas-ili-ornegi

Bayrakdaroglu, A., Şan, F.B. (2014). Financial literacy training as a strategic management tool among small medium sized businesses operating in Turkey. Procedia-Social \& Behavioral Sciences, 150, 148-155. doi: 10.1016/j.sbspro.2014.09.019

Boz, D. (2019). Kütahya ilinde bulunan özel eğitim kurumlarında öğrenim gören öğrenci velilerinin finansal okuryazarlık düzeylerinin belirlenmesi. Muhasebe ve Finansman Dergisi, 82, 147160. doi:10.25095/mufad.536036

Cole, S., Sampson, T. ve Zia, B. (2009). Financial literacy, financial decisions and the demand for financial services: Evidence from India and Indonesia. Harvard Business School Working Paper. Erişim adresi: https://www.econbiz.de/Record/financial-literacy-financial-decisions-and-the-demand-for-financialservices-evidence-from-india-and-indonesia-cole-shawn/10003842114

Çelikkol, H., Çelikkol, M. ve Özkan, N. (2017). Dumlupınar Üniversitesi akademik personelinin finansal okuryazarlık düzeyi üzerine bir araştırma. MANAS Sosyal Araştırmalar Dergisi, 6(4), 447-461. Erişim adresi: https://dergipark.org.tr/tr/pub/mjss/issue/40527/486298

Disney, R., Gathergood, J. (2013). Financial literacy and consumer credit portfolios. Journal of Banking \& Finance, 37, 2246-2254. doi.org/10.1016/j.jbankfin.2013.01.013

Durmuşkaya, S., Kavas, Y. (2018). Akademik gelişim ve finansal okuryazarlık arasındaki ilişkinin tespiti üzerine bir araştırma. Yönetim ve Ekonomi: Celal Bayar Üniversitesi İktisadi ve İdari Bilimler Fakültesi Dergisi, 25(3), 925-939. doi:10.18657/yonveek.441375

Ekolu, S. O., Quainoo, H. (2019). Reliability of assessments in engineering education using Cronbach's alpha, KR and split-half methods. Global Journal of Engineering Education,1, 24-29. Erişim adresi: http://www.wiete.com.au/journals/GJEE/Publish/vol21no1/03-Ekolu-S.pdf 
Fettahoğlu, S. (2015). Hane halkının finans eğitimi ve finansal okuryazarlık düzeyleri üzerine Kocaeli'nde bir araştırma. Muhasebe ve Finansman Dergisi, 67, 101-116. doi:10.25095/mufad.396581

Gutnu, M. M., Cihangir, M. (2015). Finansal okuryazarlık: Osmaniye Korkut Ata Üniversitesi personeli üzerinde bir araştırma. Akademik Sosyal Araştırmalar Dergisi, 10, 415-424. doi: 10.16992/ASOS.547

Güler, E., Tunahan, H. (2017). Finansal okuryazarlık: Hane halkı üzerine bir araştırma. İşletme Bilimi Dergisi, 5(3), 79-104. doi: 10.22139/jobs.323261

Güneş, F. (1997). Okuma-yazma öğretimi ve beyin teknolojisi. Ankara: Ocak Yayınları.

Güney, S., Tanyıldızı, H. (2018). Finansal okuryazarlık: AĞRI esnaf ve sanatkârlarına yönelik bir araştırma. Econharran Harran Üniversitesi İ̈BF Dergisi, 2(2), 1-21. Erişim adresi: https://dergipark.org.tr/tr/pub/econharran/issue/38815/451260

Kaderli, Y., Gümüş, U. T. ve Danışman, E. (2016). Finansal okuryazarlık düzeyinin belirlenmesi: Türk Silahlı Kuvvetleri emekli personeli üzerinde bir araştırma. Finans ve Bankacılık Çalışmaları Dergisi, 5(5), 5270. doi:10.20525/ijfbs.v5i5.635

Kılınç, E., Antepli, A. (2020). Bazı sosyo-demografik değişkenler açısından kamu çalışanlarının finansal okuryazarlık düzeylerinin incelenmesi. Selçuk Üniversitesi Sosyal Bilimler Enstitüsü Dergisi, 43, 96-109. Erişim adresi: http://dergisosyalbil.selcuk.edu.tr/susbed/article/view/1747

Kıran, F., Çetinkaya Bozkurt, Ö. (2019). Finansal okuryazarlık seviyesinin demografik değişkenlere göre incelenmesi: Batı Akdeniz girişimcileri üzerine bir araştırma. Girişimcilik ve İnovasyon Yönetimi Dergisi, 2, 68-96. Erişim adresi: https://dergipark.org.tr/tr/pub/jeim/issue/60020/867207

Klapper, L., Lusardi, A. ve Panos, G. A. (2012). Financial literacy and the financial crisis. Policy Research Working Paper 5980, World Bank. Erişim adresi: https://www.nber.org/system/files/working_papers/w17930/w17930.pdf

Kurt, A. A., Orhan, D., Yaman, F., Solak, M. Ş. ve Türkan, F. (2014). Bilgi ve iletişim teknolojileri 1şı̆̆ında Türkiye'de yapılan okuryazarlık çalışmalarındaki eğilim. Eğitim Teknolojileri Araştırmaları Dergisi, 5(2). Erişim adresi: https://www.idealonline.com.tr/IdealOnline/lookAtPublications/paperDetail.xhtml?uId=5687

Lusardi, A. (2008). Financial literacy: An essential tool for informed consumer choice?. NBER Working Paper, National Bureau of Economic Research. Erişim adresi: https://www.nber.org/system/files/working_papers/w14084/w14084.pdf

Lusardi, A., Mitchell, O.S. ve Curto, V. (2009). Financial literacy and financial sophistication among older American's?. NBER Working Paper, National Bureau of Economic Research. Erişim adresi: https://www.nber.org/system/files/working_papers/w15469/w15469.pdf

Lusardi, A., Mitchell, O. S. ve Curto, V. (2010). Financial literacy among the young: Evidence and implications for consumer policy. NBER Working Paper, National Bureau of Economic Research. Erişim adresi: https://www.nber.org/system/files/working_papers/w15352/w15352.pdf

Öztürk, E., Demir, Y. (2015). Finansal okuryazarlık ve para yönetimi: Süleyman Demirel Üniversitesi akademik personel üzerine bir uygulama. Muhasebe ve Finansman Dergisi, 68, 113-134. doi:10.25095/mufad.396629

Sarıgül, H. (2015). Finansal okuryazarlık tutum ve davranış ölçeği: Geliştirme, geçerlik ve güvenirlik. Yönetim ve Ekonomi Araştırmaları Dergisi, 13(1), 200-218. doi:10.11611/JMER408 
Serinkan, C., Erdoğan, M. (2018). Yöneticilerin finansal okuryazarlık düzeylerinin belirlenmesi: Bişkek örneği. 1. Uluslararası Ekonomi ve İşletme Sempozyumu.

Sevim, N., Temizel, F. ve Sayllır, Ö. (2012). The effects of financial literacy on the borrowing behavior of Turkish financial consumers. International Journal of Consumer Studies, 36(5), 573-579. Erişim adresi: https://www.researchgate.net/publication/263251710_The_effects_of_financial_literacy_on_the_borro wing_behavior_of_Turkish_financial_consumers

Şahin, M., Barış, S. (2017). Finansal okuryazarlık ve tasarruf davranışları: Kamu çalışanları üzerine bir inceleme. Çankırı Karatekin Üniversitesi İktisadi ve İdari Bilimler Fakültesi, 7(2), 77-103. doi:10.18074/ckuiibfd.332555

Mercan, N., Oyur, E., Altınay, A. ve Aksanyar, Y. (2012). Ekonomi okuryazarlığına yönelik ampirik bir araştırma. Ekonomi Bilimler Dergisi, 4(2), 109-118. Erişim adresi: https://dergipark.org.tr/tr/download/article-file/56719

Ünal, S., Düger, Y. S. (2011). Akademik personelin finansal gönenç hâli ile finansal davranış eğilimi arasındaki ilişkiye yönelik ampirik bir araştırma. Ekonomik ve Sosyal Araştırmalar Dergisi, 1, 213-226. Erişim adresi: https://dergipark.org.tr/tr/pub/esad/issue/38955/456062

Ünal, S., Boz, D. ve Ataşer, A. (2019). Bireysel emeklilik sistemi üyeliği ve bazı demografik değişkenlerin finansal okuryazarlık ile ilişkisi. Sosyal Bilimler Metinleri, 2, 104-115. Erişim adresi: https://dergipark.org.tr/tr/download/article-file/882031

Van Rooji, M., Lusardi, A. ve Alessie, R. (2011). Financial literacy and retirement planning in the Netherlands. Journal of Economic Psychology, 32, 593-608. doi:10.1016/j.joep.2011.02.004

Yardımcıoğlu, M., Yörük, A. (2016). Türkiye'deki finansal okuryazarlığın ve finansal farkındalığın durumu. Muhasebe ve Vergi Uygulamaları Dergisi, 9(2), 173-208. Erişim adresi: https://dergipark.org.tr/tr/download/article-file/1521220

\section{Extended Abstract}

\section{Purpose}

The aim of the study is to examine whether there is a difference among scientists in terms of the components of the Financial Literacy Attitude and Behavior Scale (spending, perception, interest and attitude), the knowledge levels of scientists about financial concepts and whether there is a relationship between the components of the attitude and behavior scale.

\section{Design and Methodology}

The research population consists of academic staff working at Niğde Ömer Halisdemir University. The data is collected in March 2019. As of this date, it has been determined that 951 academicians work at Niğde Ömer Halisdemir University, according to the released statistics on the official website of the Council of Higher Education. While the data were collected by survey method, convenience sampling was adopted. The applied questionnaire consists of three parts and 49 questions. A face-to-face questionnaire was applied to the academicians who participated in the research on a voluntary basis. 247 valid responses were provided. The sample size of 247 observations corresponds to a margin of error of $5.37 \%$ at the $95 \%$ confidence level. 
In the study, firstly, the profile of the participants was revealed by using descriptive statistics. In the second stage, factor analysis was used in order to collect the items in the financial literacy attitude and behavior scale that are related to each other in a group and to make a dimension reduction. Finally, the existence of a relationship between the dimensions obtained from factor analysis and demographic characteristics was determined with the help of non-parametric tests.

Bartlett's test was significant ( $\mathrm{p}=0.000$ and $<0.05$ ). The Kaiser-Meyer-Olkin sample adequacy index is 0.795 . Therefore, the collected data was suitable for factor analysis.

\section{Findings}

According to descriptive findings, $75 \%$ of the participants were married and $21 \%$ were never married. The vast majority (61.54\%) have doctoral education. While $37.66 \%$ are in the $41-50$ age range, $32.39 \%$ are in the $31-40$ age range. Academic titles of the participants are as follows: $27.94 \%$ of the participants are Assistant Professors, $17 \%$ of them are Associate Professors, $21.05 \%$ of them are lecturers and $17.41 \%$ of them are research assistants. In terms of following the economic news, more than half of the participants (52.63\%) follow them regularly. In addition, in terms of household average income, 34.01\% of the participants have an income of 5.000-7.500, 29.15\% of them have 7.501-10.000 and 5.26\% of them have an income of 15.000 and above.

The relationships between demographic variables and the dimensions revealed by factor analysis are as follows: Between "gender" and "interest" and "perception" sub-dimensions, between title and "spending" and "attitude", between following economic developments and "spending," There were significant differences between the sub-dimensions of "attitude", "interest", and between age and "perception" sub-dimensions.

There were also significant differences between some of the financial concepts (which are savings, stocks, mutual funds, participation banks, private pensions, investments, inflation, checks) and financial literacy attitude and behavior components.

\section{Research Limitations}

The research was carried out in the summer period when the education period ended and this limited the sample size. In addition, convenience sampling, which is one of the non-random sampling methods due to time constraints, causes the findings to be limited to the sample. It limits generalizations about the population.

\section{Implications (Theoretical, Practical and Social)}

Financial literacy attitudes and behaviors of scientists working in different disciplines can be examined on a larger population and sample based on random sampling, especially in their fields of expertise.

\section{Originality/Value}

Studies in the literature mostly focused on determining the financial literacy levels of the participants. However, studies on examining financial literacy attitudes and behaviors are relatively limited. Also, these studies are mostly aimed at university students. But financial attitude and behavior is an issue that needs to be investigated for audiences other than students. In this study, financial literacy attitudes and behaviors of academicians are discussed. Because there is no study in the literature that examines financial literacy attitudes and behaviors of academicians in their fields of study. This aspect of the study is expected to contribute to the literature.

Araştırmacı Katkısı: Fevzi Serkan ÖZDEMİR (\%25), Haluk BENGÜ (\%25), Elif BULUT (\%25), Serpil ÇELİK \%25). 